\title{
The Innovation and Adoption of Iron in the Ancient Near
}

\section{East}

\author{
Nathaniel L. Erb-Satullo ${ }^{1}$
}

Published online: 21 February 2019

(c) The Author(s) 2019

\begin{abstract}
This review synthesizes field research, textual analysis, and archaeometric data to evaluate different explanations for the spread of iron in the ancient Near East. Current evidence supports an Anatolian origin for extractive iron metallurgy on a limited scale sometime in the early 2 nd millennium BC. However, the first major expansion of iron, both in Anatolia and across the wider Near East, occurred in the late second and early first millennium BC. Explanations that place iron adoption within its broader social context are favored over those that consider material or geological properties in isolation. A recurring theme is the importance of comparative analysis, both geographically and between the iron and bronze economies, to explore how social, political, and economic conditions affected adoption patterns.
\end{abstract}

Keywords Technology $\cdot$ Iron Age $\cdot$ Metallurgy $\cdot$ Craft production $\cdot$ Smelting

\section{Introduction}

In the middle of the second millennium $\mathrm{BC}$, iron was a rare and valuable material. A thousand years later, iron use had spread across large swaths of Eurasia. Though iron likely did not immediately transform societies that adopted it, over the long term it assumed an important role in warfare and agriculture. Because of the importance of iron and steel in modern industry, the origin of iron has attracted significant interest within the study of early innovations. Theories about the origins and impact of iron have a long history (e.g., Childe 1944, p. 20; Engels 1902, p. 197), and the view that iron technology "democratized" access to metal is a common refrain. Yet, an innovation's consequences must not be conflated with the causes for its initial adoption. Though some earlier models saw iron technology and the invasion of iron-bearing peoples as a central cause of

Nathaniel L. Erb-Satullo

nathaniel.erb-satullo@arch.ox.ac.uk

1 Research Laboratory for Archaeology and the History of Art, School of Archaeology, University of Oxford, 1 South Parks Rd, Oxford OX1 3TG, UK 
sociopolitical changes at the end of the Bronze Age (Richardson 1934), those technologically deterministic explanations have long since been abandoned for more nuanced theories involving many factors (e.g., Knapp 2013, p. 447; Sherratt 1998). In some parts of the Near East, widespread iron adoption is certainly connected with the collapse of Late Bronze Age empires and subsequent sociopolitical developments, though archaeologists now see iron innovation as a result of these developments rather than a cause (Mirau 1997; Sherratt 2000; Veldhuijzen 2012).

The topic of iron innovation in the Near East merits a regional synthesis for several reasons. Though a number of studies have considered iron innovation from the perspective of individual subregions (McConchie 2004; McNutt 1990; Nieling 2009; Waldbaum 1999; Yahalom-Mack and Eliyahu-Behar 2015), it has been some time since this topic has seen a broad comparative treatment (e.g., Moorey 1999, pp. 278-292; Wertime and Muhly 1980). Secondly, a regional synthesis provides an opportunity to inject discussions about early iron into broader debates about invention, innovation, and technological change. Recent years have seen an increase in archaeological interest in this topic, often drawing on the innovation-diffusion literature in neighboring disciplines (e.g., Baldi and Roux 2016; Burmeister and Bernbeck 2017; Maran and Stockhammer 2017; Rogers 2003; Thér et al. 2017). Encouragingly, there has been a productive trend toward integrating archaeometallurgical research into these discussions (Charlton et al. 2010; Killick 2015; Lam 2014; Radivojević 2015; Roberts and Radivojević 2015; Thornton 2009a). Several studies of iron adoption have begun to engage with these broader theoretical issues, but these have largely focused on regions outside the Near East (Barceló et al. 2014; Kim 2001; Meyer 2017).

Depending on the region, the Bronze Age-Iron Age transition in the Near East (Fig. 1) is usually dated to $1200-1000$ BC. As we shall see, however, transformations in iron use began before and continued long after this 200 -year period. It is imperative, therefore, to distinguish between the chronological period termed the Iron Age, the origins of extractive iron metallurgy (i.e., smelting), and the periods in which iron achieved widespread usage. In many areas, these events took place at radically different times.

Research on the Levant has played a dominant role in the development of models of the organization of Near Eastern metal production and technological change (see Thornton 2009b). This is particularly true for the study of iron innovation. Indeed, the massive quantity of research on Late Bronze (LBA) and Early Iron Age (EIA) southern Levant (Fig. 2) has provided a rich and textured dataset that is unmatched elsewhere. Cyprus (Fig. 3) also has seen a wealth of research on Late Bronze and Early Iron Age metallurgy, though copper and its alloys have received more attention than iron. Research in other regions of the Near East, such as Anatolia (Fig. 4), the Caucasus (Fig. 5), and Iran, has the potential to test models of technological change in distinct yet adjacent regions. While I recognize the importance of Levantine and eastern Mediterranean data to discussions of the origins of iron, my review also covers areas of the Near East, such as the Caucasus, that remained peripheral to these earlier discussions. A comparative examination of iron innovation in these different areas offers a series of relatively "controlled" case studies in which to examine the impact of varying social conditions on the adoption process. 


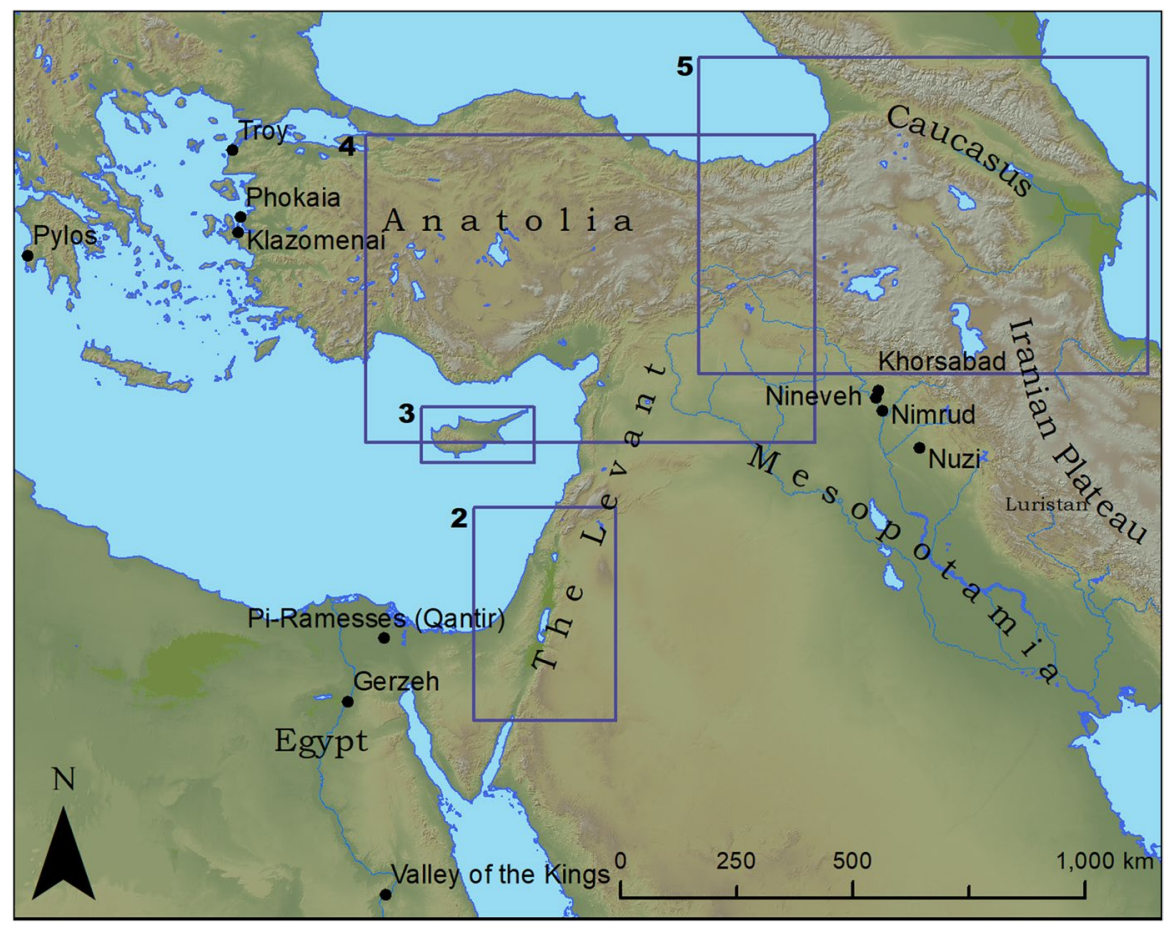

Fig. 1 Map of the Near East, showing sites mentioned in the text and the locations of maps in Figs. 2-5

This review begins with an evaluation of the evidence for the adoption of iron in the Near East, from its earliest appearance through its widespread adoption by circa 600 BC. I discuss methods for distinguishing meteoritic and smelted iron, evaluate references to iron in ancient texts, and sketch regional trajectories of iron adoption. Anatolia has the most robust textual, archaeological, and analytical evidence for early smelted iron, beginning a little after 2000 BC. In the second part of the review, I examine in detail various explanations for why iron use increased dramatically around the turn of the first millennium BC. Much scholarship has tried to identify what might be termed iron's "competitive advantage"-namely, what characteristics of iron or iron production systems might have made it more appealing than bronze. The material properties of early iron are considered in detail, as the perception that the relative hardness of iron drove adoption has influenced popular and scholarly investigations of the origins of iron (e.g., Muhly 2003, p. 180). In fact, there is little evidence for the contention that consistent carburization and quenching, which are needed to make iron much harder than bronze, were driving factors in the initial surge of iron adoption. The relative geological distribution of iron, copper, and tin ores, along with the associated economic implications for the spread of iron, is also a major consideration. A synthesis of existing scholarship shows that an exclusive focus on material or geological properties alone provides, at best, an incomplete understanding of this transformation. This section also charts evolving perspectives on various "shortage" hypotheses, which posit that a collapse in trade 


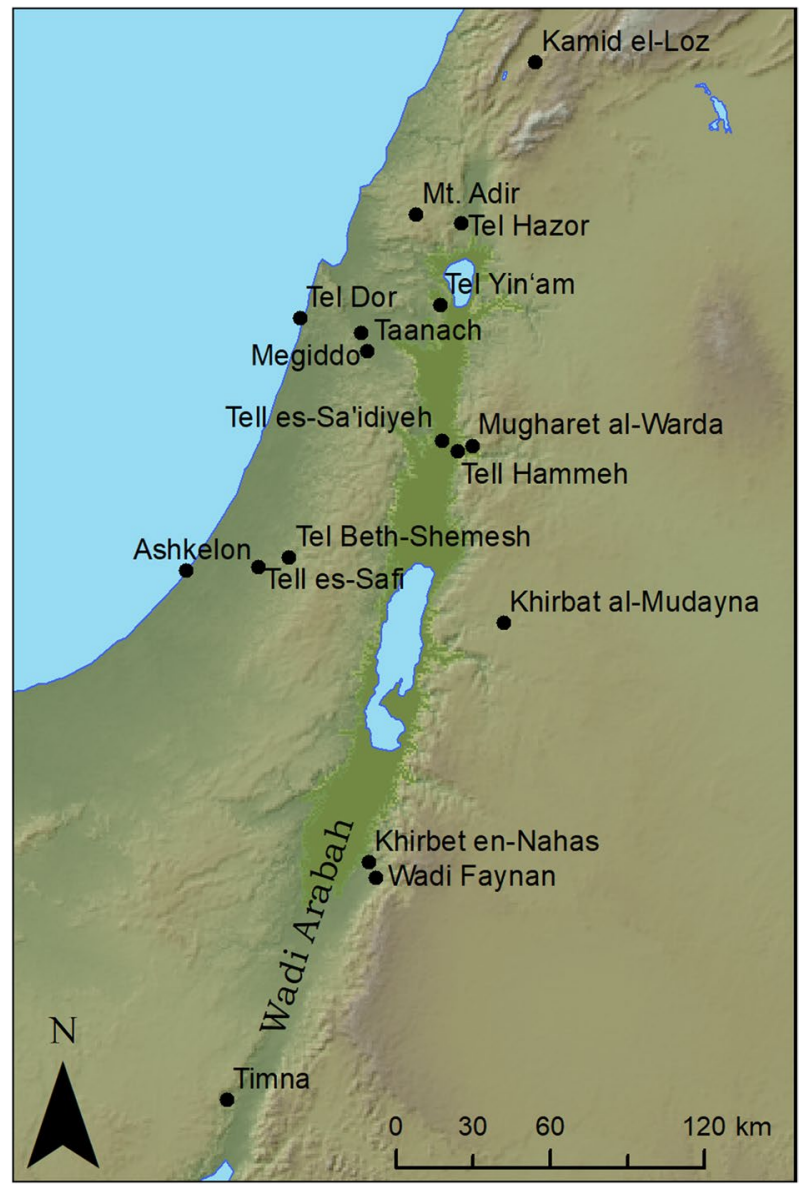

Fig. 2 Map of the southern Levant, showing sites mentioned in the text

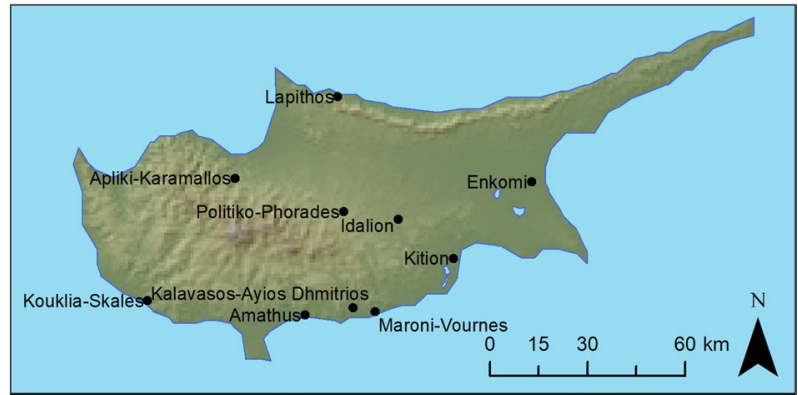

Fig. 3 Map of the Cyprus, showing sites mentioned in the text 


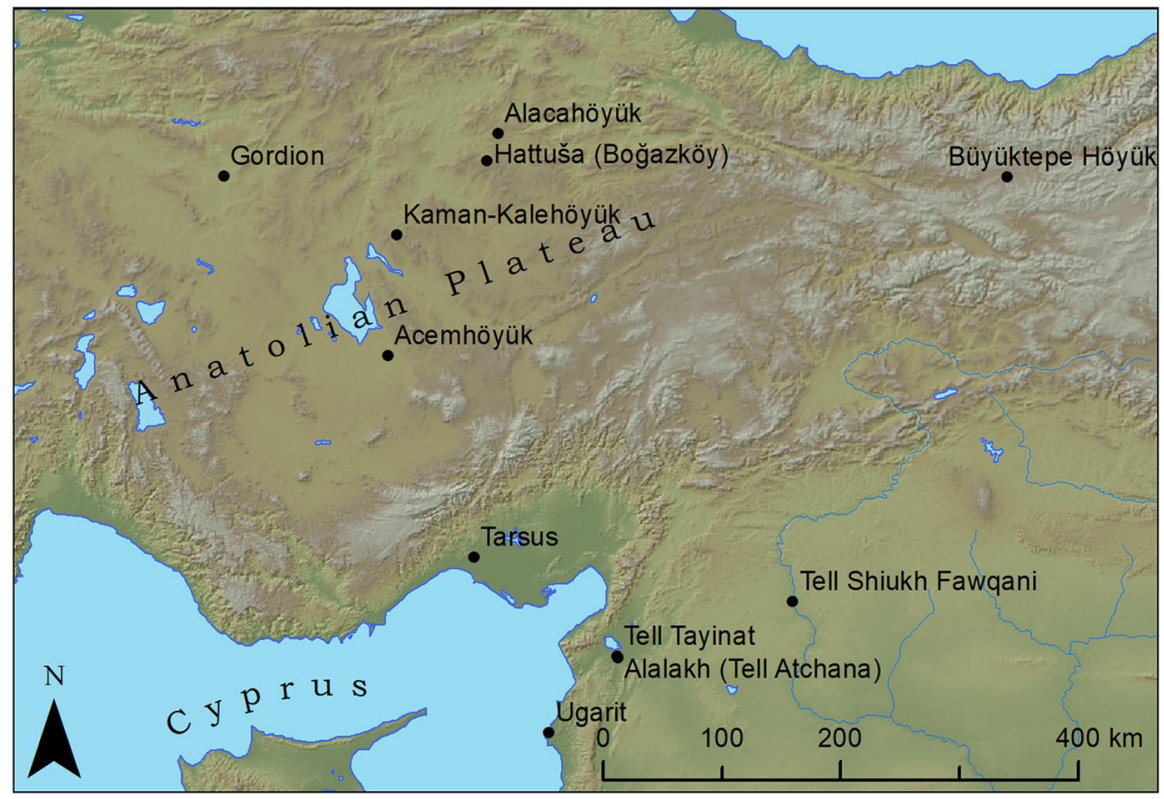

Fig. 4 Map of Anatolia, the northern Levant, and part of Mesopotamia, showing sites mentioned in the text

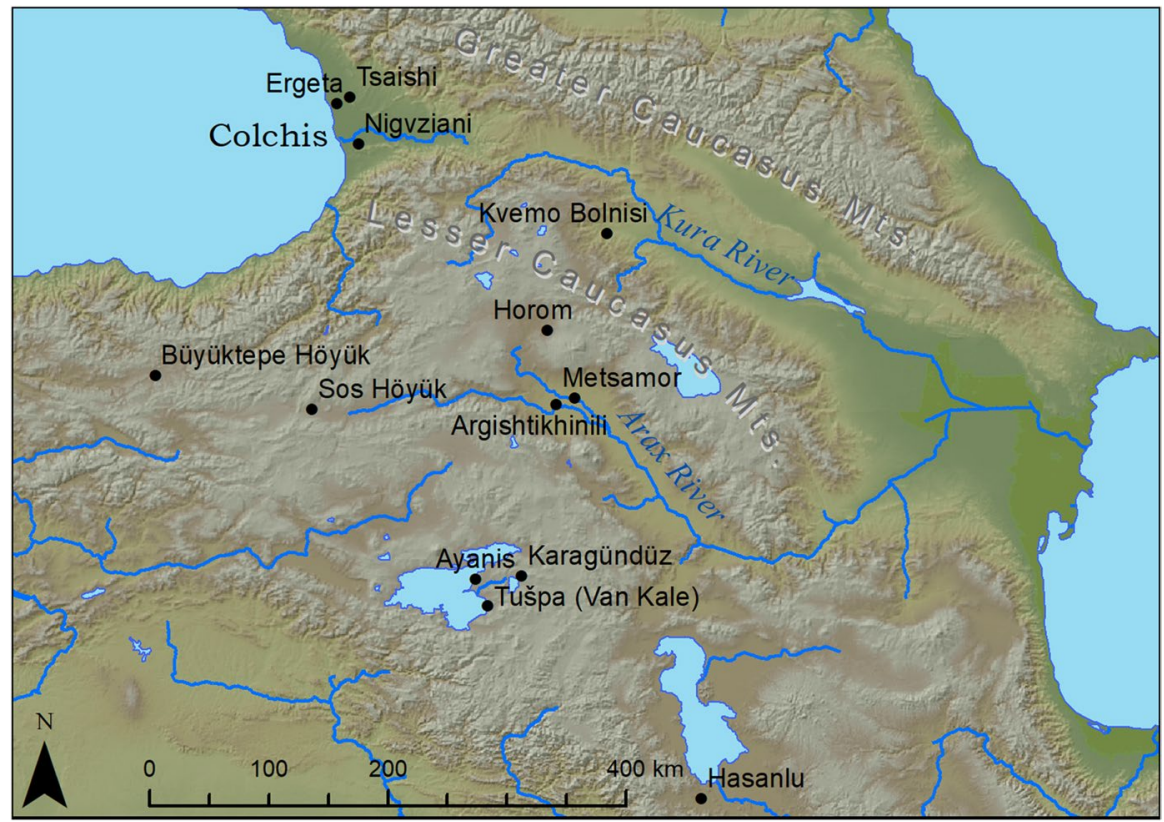

Fig. 5 Map of the Caucasus, showing sites mentioned in the text 
networks supplying copper and tin caused the adoption of iron. While these "shortage" models proved unsatisfactory, iron adoption in the eastern Mediterranean is still understood as a key part of the major economic and political realignments in the Early Iron Age.

To highlight the importance of assessing the social context of technologies in relation to their spread, the subsequent section examines what production sites reveal about the organization and practice of iron and copper alloy metallurgy during the early periods of iron use. I contend that this technological transformation can be understood only by examining the social context of iron and copper alloy metallurgy in tandem. How were metalworkers organized, and what was their relationship with metal consumers, whether elite or nonelite? To what extent were metal economies administered from institutions of political control? A full discussion of these issues for all parts of the Near East is not possible within the limits of this review, but recent work has made an initial evaluation of the more intensively studied regions possible. A final section highlights the most promising areas for future work on early iron innovation, emphasizing close interaction between field and laboratory research.

\section{Tracking the Spread of Iron}

\section{Earliest Iron (c. 3300-1200 BC)}

Before the second millennium BC, iron is reported only in small quantities. Waldbaum (1980, pp. 69-70) identified 14 iron artifacts from Iran, Mesopotamia, and Egypt that supposedly date to before $3000 \mathrm{BC}$, but a number of these are likely intrusive or incorrectly identified as metallic iron (see Rehren et al. 2013, p. 4785 and references therein). Nevertheless, some early artifacts have been confirmed as metallic iron by scientific analysis. Recent research on beads from Gerzeh, a Naqada period site in Egypt (c. 3400-3100 BC), showed that they were meteoritic iron (Johnson et al. 2013; Rehren et al. 2013). Iron has been found at a number of thirdmillennium BC sites in Anatolia, such as Tarsus, Troy (Level II), and Alaca Höyük (Yalçin 1999, p. 178), but only a portion have been scientifically analyzed (e.g., Nakai et al. 2008).

Larger numbers of iron artifacts, too many to list individually, appeared in the second millennium BC. Waldbaum $(1978,1980,1999)$ produced several early syntheses of available references to iron in the Bronze Age Mediterranean and parts of the Near East, totaling about 150 artifacts. The majority of these come from the Late Bronze Age (c. 1600-1200 BC). Moorey (1999, p. 278) provides a similar listing for Mesopotamia. Recently discovered iron artifacts at Kaman-Kalehöyük, one of which has been dated to the late third millennium BC, can now be added to earlier syntheses of Bronze Age iron (Akanuma 2006, 2008).

Early iron artifacts come in a wide range of forms. Some examples, such as the (unanalyzed) iron studs associated with gold and lapis lazuli on an ivory box recovered at Acemhöyük (level III, c. 18th century BC) (Özgüç 1976), are used in a clearly decorative context. The close association between iron and other costly 
materials strongly suggests that it was highly valued. A classic example is the gold and iron dagger in the 14th-century BC tomb of Tutankhamun in the Valley of the Kings (Comelli et al. 2016). Old Assyrian trade colony texts found at KultepeKanesh support this interpretation, recording that iron was as much as 40 times more valuable than silver by weight (Dercksen 2005, p. 28; Muhly 1980, p. 36).

Two key issues complicate discussions of the earliest iron in the Near East: the identification of iron smelted from ores, and the challenges of correlating archaeological evidence and textual accounts. Metallic iron is found in meteorites, as well as in rare terrestrial deposits of native (telluric) metal, so determining the origin of early iron artifacts is of paramount importance for dating the beginnings of iron smelting. References to "sky-iron" in Hittite texts are read by some as meaning iron from meteorites, while others suggest it might refer to the color attributes of a particular type of smelted iron (Yalçin 1999, pp. 183-184). Telluric (naturally occurring terrestrial metallic) iron is extremely rare and most deposits are very small; its exploitation seems to have been restricted to Inuit populations in Greenland (Buchwald 1992; Yalçin 1999, p. 184). There are geological reports of grains of telluric iron in the southern Levant (Britvin et al. 2015), but there is no evidence that this was ever exploited.

Analytically, there are several methods for distinguishing between meteoritic and smelted iron. High nickel content in the range of 6-20\% is often flagged as indicative of a meteoritic origin, based on comparisons with meteorite chemistry (Yalçin 1999, pp. 180-181). Corrosion can affect the composition of iron, so measurements must be taken on uncorroded metal, or corrosion must be taken into account in when results are interpreted (Jambon 2017). Analyses show that many early iron artifacts contain nickel (Waldbaum 1980, pp. 69-74). In Anatolia, Yalçin (1999, p. 184) notes that many early iron artifacts do contain nickel, but in concentrations that are usually less than 3\%. The situation is complicated by the fact that some terrestrial iron ores, including some possible ore sources in Anatolia, do contain nickel, and archaeological evidence from Hellenistic Greece suggests that at least some ores of this type were exploited in antiquity (Moorey 1999, p. 279; Photos 1989). Other scholars, however, doubt that nickel-rich terrestrial ores could explain the chemical composition of early iron artifacts (Jambon 2017, p. 51). The presence of other elements, such as germanium, as well as a Ni/Co ratio of about 18:1, has also been considered diagnostic (Comelli et al. 2016, p. 1306; Jambon 2017; Rehren et al. 2013, p. 4790). Many of these more recent studies have developed nondestructive approaches that take alteration into account, improving the accuracy of these determinations. Another feature of some iron meteorites is the Widmanstätten microstructure, consisting of alternating bands of nickel-rich kamacite and taenite, observable by examination of a polished sample under a microscope. Such microstructures have been identified in some early iron artifacts (Johnson et al. 2013), but not all meteorites have this structure, and forging at high temperatures can eliminate it (Photos 1989, pp. 404-407).

Nevertheless, a suite of recent analyses that address earlier analytical issues strongly suggests that meteorites were used to fashion early iron objects. The meteoritic iron beads from Gerzeh have already been mentioned above (Johnson et al. 2013; Rehren et al. 2013), while new chemical analysis supports a meteoritic origin 
for the Tutankhamun dagger (Comelli et al. 2016), an ax made of iron, bronze, and gold from Ugarit, and other Bronze Age iron artifacts (Jambon 2017). These recent studies have simultaneously strengthened the case for meteoritic iron and weakened evidence for smelted iron at this early stage. Some ambiguities remain, for instance, concerning various iron objects from Early Bronze Age Alaca Höyük (Jambon 2017, supplementary material; Nakai et al. 2008; Yalçin 1999, p. 180). Metallographic studies of Late Bronze Age iron from Alaca Höyük show slag inclusions typical of smelted iron (Muhly et al. 1985), though at least one of the authors later suggested that those inclusions might have been introduced during smithing (see Yalçin 1999, p. 185). More recent analysis of iron artifacts from Kaman-Kalehöyük also shows slag inclusions in iron artifacts from the Old Assyrian Colony period (Level IIIc, 20th-18th centuries BC) and possibly in one heavily corroded iron object from the Early Bronze Age (Level IVa, 22nd-20th centuries BC), though the angular morphology of one putative slag inclusion in the latter artifact is odd (Akanuma 2003, 2008). Though the heavy corrosion necessitates caution, chemical compositions (Ni/ $\mathrm{Co}$ and $\mathrm{Ni} / \mathrm{Fe}$ ratios) of the artifacts are outside the ranges for meteoritic iron defined by Jambon (2017).

There is no substantial evidence of iron smelting (furnaces or slag) in the Middle East prior to $1000 \mathrm{BC}$. One early possibility, a pyrotechnological installation at Tel Yin'am dating to the 13th century BC (Liebowitz 1981, pp. 83-84), has been refuted on the grounds of low iron content, the mineralogical content of the slag, and other lines of evidence (Pigott 2003). Another possibility, excavated at 13th-century BC Kamid el-Loz, is also doubtful (Veldhuijzen and Rehren 2007, p. 190). The excavations at Kaman-Kalehöyük yielded a possible piece of ore dating to the Hittite period, but the iron-bearing mineral may have been used as pigment rather than for smelting (Akanuma 2006, pp. 216, 219-220). The earliest piece of iron production debris at this site, and indeed anywhere, is a heavily corroded lump about $3 \mathrm{~cm}$ wide, originally dated to the Old Hittite period (Stratum IIIb), but later assigned to the Old Assyrian Colony period (Stratum IIIc) (Akanuma 2007, pp. 125-127). The heavily corroded microstructure of the lump consists of dendrites of what is either corroded iron metal or wüstite, along with silicate laths that might be fayalite. The identification of iron metallurgical debris seems fairly secure, though iron oxide dendrites and metallic iron can occur in copper production slags. Based on published evidence, it is not possible say whether this slag fragment came from a smelting or a smithing operation. Regardless, if the dating is correct, this would be the earliest example of iron metallurgical debris of any kind.

Textual evidence, especially from Anatolia, is an important source of evidence on the beginning of iron use. Iron is referred to using several different terms. In the early second-millennium BC Kültepe-Kanesh texts, šaduānum (most likely hematite), parzillum, KÙ.AN, amūtum, and ašium are commonly mentioned, while Hittites referred to iron using AN.BAR or AN.BAR GE 6 , among others (Dercksen 2005, pp. 27-28; Košak 1986; Maxwell-Hyslop 1972; Muhly et al. 1985; Yalçin 1999, pp. 182-184). Scholars have attempted to map these ancient terms onto modern categories of metallic iron (e.g., smelted, meteoritic) and iron-bearing minerals (e.g., hematite, magnetite, and goethite) with varying degrees of certainty (Dercksen 2005). Unfortunately, ancient Mesopotamian and Anatolian categorizations of iron 
may not match modern terminology, which poses some problems for identifying the origins of iron smelting. Nevertheless, contextual clues-for instance, the phrase AN.BAR ŠA GUNNI (iron straight from the furnace) in Hittite texts-do suggest that some of these words do refer to smelted iron (Yalçin 1999, p. 184).

The texts provide a supplementary picture of iron metallurgy in the early-mid second millennium BC, when iron artifacts are rare. In the Old Assyrian period texts (early second millennium BC), iron is clearly highly valued, traded in small quantities, and often difficult to obtain (Dercksen 2005; Larsen 2015, pp. 118, 219; Veenhof 2016). Some of the many terms used for iron may refer to meteoritic iron or even iron-bearing minerals (e.g., hematite). Some readings have also been revised. An 18th-century BC text from Alalakh that mentions 400 iron weapons is occasionally mentioned in the literature (Yalçin 1999, p. 182), but the reading of the word iron is due to a speculative, and ultimately unlikely, reconstruction of a broken section of tablet (Brinkman 1987; Moorey 1999, p. 288). In the same note, Brinkman also corrects an erroneous mention of iron scale armor from Late Bronze Age Nuzi. On the other hand, Hittite texts (mostly from the late Empire period) mention an iron throne, a scepter, and a 45-kg iron basin that presumably represent a fairly large quantity of metal (Košak 1986; Muhly et al. 1985, pp. 73-74; Yalçin 1999, pp. 182, 184).

Old Kingdom Hittite records mention ironworkers in a text associated with religious festivals, but the most famous reference to iron in the Bronze Age occurred in a 13th-century BC letter from the Hittite King Hattušili III to an Assyrian king: “... concerning the good iron which you mentioned in your letter, the store in Kizzuwatna has run out of good iron. I wrote to you that it is not a suitable time to produce iron. They will produce iron but they have not finished yet. When they have finished I will send it to you. Now I am sending you an iron (sword/dagger) point..." (Siegelova 1984, p. 156; as reported in Yalçin 1999, p. 183). This brief missive has been heavily discussed by scholars. Older theories of Hittite state monopoly on iron that aided their military dominance have been convincingly rejected (Košak 1986; Waldbaum 1999, p. 32). A more modest and reasonable interpretation is that the Hittite state was involved in the production of iron, potentially more so than its neighbors to the south but certainly not to the level of a strategic monopoly (Burney 2004, pp. 135-136; McNutt 1990, p. 140; Muhly 2003, p. 180; Snodgrass 1980, p. 357; Waldbaum 1980, p. 81).

These twin challenges - the difficulties of assessing textual references and analytically distinguishing smelted and meteoritic iron-hinder efforts to draw definite conclusions about the earliest iron smelting. Still, recent research has caused the various strands of evidence to coalesce into an increasingly coherent picture. Most of the recent high-quality analyses of iron artifacts have shown that iron artifacts dating to before $2000 \mathrm{BC}$ are made from meteoritic iron (Jambon 2017; Johnson et al. 2013; Rehren et al. 2013). Both textual (Dercksen 2005, p. 27) and analytical evidence (Akanuma 2003) from Anatolia suggest that small quantities of iron were smelted in the early second millennium BC. There was a noticeable increase in references to iron in texts of the late Hittite Empire period (especially during and after the 13th century BC) (Yalçin 1999, p. 184), but that may be due to differences in the kinds of written records that are preserved from different parts of the Hittite period 
(Cordani 2016; Košak 1986). The degree to which the expansion of iron in later periods can be linked to Hittite-period technical innovations remains unclear.

In sum, although different lines of evidence point to Anatolia as the origin of extractive iron metallurgy, the overall picture might yet change because of the dearth of analytical work on early iron artifacts and the possibility that certain isolated early artifacts may be later intrusions (e.g., Eliyahu-Behar and Yahalom-Mack 2018, p. 460; Rehren et al. 2013, p. 4785). The reasons for the nearly thousand-year delay between the first smelted iron and its wide adoption are unclear. Either technological, sociocultural, or economic conditions prevented its consistent production until the end of the second millennium BC. A possible, though still unproven explanation is that early smelted iron was an accidental byproduct of other metallurgical processes (see Merkel and Barrett 2000; Wertime 1973, pp. 878, 885 and discussion below). Yet another possibility is that very early iron-smelting technology yielded only small "mini-blooms" that were subsequently forged together, limiting the scale of production (Pigott 1981, pp. 82-84). Technological limitations on consistent production are likely factors, given how much iron was valued.

\section{Iron in the Iron Age (1200-600 BC)}

Iron artifacts appear more regularly in archaeological contexts after $1200 \mathrm{BC}$, but there is significant variability from region to region. Many important syntheses of patterns of adoption in various regions of the Near East are decades old (Pigott 1980; Snodgrass 1980; Waldbaum 1980, 1999). In discussing iron innovation, I consider the centuries-long adoption process following the first appearance in a region, a period that often extended well into the first millennium BC. The assessment of iron use patterns in this section is organized by region, with special attention given to areas, such as the South Caucasus, that have been underemphasized in previous syntheses.

\section{Levant, Eastern Mediterranean, and Egypt}

In the eastern Mediterranean, iron artifacts appear with growing frequency in 12th and 11th-century BC contexts. Bimetallic or polymetallic objects, such as a 12thcentury BC iron dagger with copper alloy rivets from Kition (Snodgrass 1982, p. 286), are regularly found, though they are by no means exclusive to the initial periods of iron use (Waldbaum 1982). Additional iron blades, sometimes with decorations of gold and silver, have also been found in the 11th-century BC cemetery of Kouklia-Skales (sometimes called Paleopaphos-Skales) (Karageorghis 1982, 1983). Often, iron artifacts repeat forms seen in bronze (Karageorghis and Raptou 2016, pp. 91-92; Snodgrass 1982, p. 286). In an admirable early attempt at quantitative comparisons between regions, Snodgrass (1982, pp. 287-288) identified Cyprus, followed closely by the southern Levant, as early adopters.

Unfortunately, cross-regional comparisons are hindered by the unevenness of archaeological research. One also must acknowledge that, here and elsewhere, cultural traditions may affect the selection of artifacts for placement in burials and possibly distort the overall picture of the relative abundance of bronze and iron in these 
societies (Morris 1989). As a result, early quantitative syntheses should be considered only a rough approximation of usage patterns (Rothenberg 1982, p. 295; StechWheeler et al. 1981, p. 246; Yahalom-Mack et al. 2017, p. 66). Newer syntheses of iron adoption in the southern Levant (Gottlieb 2010; Yahalom-Mack and EliyahuBehar 2015), which take into account more recent chronological adjustments to key assemblages, reveal a significant expansion in iron use during the Iron IIA period (10th-ninth century BC), though there are some interesting geographical heterogeneities in adoption patterns. These more recent studies illustrate the potential for applying quantitative approaches to studying iron adoption in geographically constrained regions. Given that recent work in the southern Levant has challenged the dating of some early iron finds (Eliyahu-Behar and Yahalom-Mack 2018, p. 460), it would be interesting to see whether a reevaluation of early Cypriot iron finds would lead to similar adjustments.

Accompanying the increasing number of iron artifacts, we begin to see a significant expansion in iron production debris, mostly dating to the Iron IIA period or later, across a number of sites, including Ashkelon, Hazor, Tel Beth Shemesh, Megiddo, Tell Hammeh, Tell es-Safi, and Tell Tayinat, to name just a few (EliyahuBehar et al. 2008; Erb-Satullo and Walton 2017; Roames 2011; Veldhuijzen and Rehren 2007; Yahalom-Mack et al. 2014a, 2017). Levantine iron workshops and their implications for the organization of production are discussed further below, but the increase in production debris is worth noting here, as it indicated a new period in the trajectory of iron adoption.

The importance of Cyprus and the Levant in the expansion of iron metallurgy cannot be underestimated. These regions contain some of the best-documented iron assemblages c. 1200-1000 BC, and the evidence of iron production after $1000 \mathrm{BC}$ is substantial. Maritime trade, spearheaded by the Phoenicians, seems to have been crucial in spreading iron technologies across the Mediterranean (Aubet 2008, pp. 248-249; Kaufman et al. 2016; Snodgrass 1980, pp. 359-360). This has led some to argue that the confluence of interregional contacts, maritime trade, and merchant infrastructure led to the precocious development of iron metallurgy in Cyprus and the Levant, rather than in more remote regions such as Anatolia or the Caucasus (Sherratt and Sherratt 2001; Sherratt 1993, 2000). Though the current evidence suggests that extractive iron metallurgy may have developed earlier in Anatolia, a scenario in which the Levant and eastern Mediterranean witnessed earlier widespread adoption is certainly plausible. Problems of Early Iron Age chronology in Anatolia (see Seeher 2010) and the varying intensity of archaeological investigation renders this model rather hypothetical at present.

In Egypt, despite its long-standing connections with the Levant and early use of meteoritic iron, the adoption of smelted iron was significantly delayed (Snodgrass 1980, pp. 364-365). The study of iron in Egypt from 1200-600 BC has received far less attention than the early meteoritic examples. Many studies on iron are from before 1950 (see references in Ogden 2000; Snodgrass 1980, p. 373), or cover material with only an approximate date and context (Williams and Maxwell-Hyslop 1973). A general consensus links an expansion of iron use with the seventh-century Assyrian invasions, but the question has not been investigated in detail. This is an unfortunate gap, as Egypt offers a potentially interesting case study in technological 
rejection, given the much earlier use of iron in the southern Levant. Moreover, the adoption of iron in Egypt is potentially crucial to discussions about the origins of iron in Africa (see Humphris and Rehren 2014; Killick 2009, 2015, pp. 310-311).

\section{Mesopotamia}

In Mesopotamia proper, investigations of iron adoption have relied predominantly on references to iron in texts, as iron is rather rare in Iron Age contexts prior to the eighth-century BC (Moorey 1999, p. 289). Textual analysis shows that iron was coveted by and restricted to elites in the 13th through tenth centuries BC (Pleiner and Bjorkman 1974, pp. 286-287). The same study traced the increasing quantities of iron referenced in Assyrian booty texts in the ninth-early eighth century, while noting that mentions of iron by later Assyrian kings declined in the late-eighth and seventh centuries. Does this reflect the fact that iron had become so common that it was not deemed worthy of note, or simply that Assyrian kings were campaigning in areas that did not produce as much iron? In 19th-century excavations, iron was found in massive quantities at Khorsabad (late eighth century BC), suggesting that it was being stockpiled in the Assyrian capital region even as its appearance in tribute texts was declining (Pleiner 1979; Pleiner and Bjorkman 1974, p. 293). A new study of Assyrian metalwork (Curtis 2013) provides an updated discussion but also focuses primarily on eighth-seventh-century BC artifacts. It is telling that by this period, iron had virtually supplanted bronze in numerous classes of artifacts (Curtis 2013, pp. 142-143), suggesting that key transitional metal assemblages are lacking for the region. Without this kind of direct evidence, it is difficult to map the pace and patterning of iron adoption in Mesopotamia in the period 1200-900 BC. Still, it is reasonable to speculate that the expansionary, metal-hungry Assyrian state would have played some role in stimulating the spread of new metal industries (Pigott 1982, p. 24).

Intriguing evidence for iron production comes from the site of Tell Shiukh Fawqani on the Euphrates, where iron metallurgical debris was dated to the late eighth to seventh centuries BC (Luciani 2016; Luciani et al. 2003). The total quantities are modest, but enough debris was found to suggest some kind of iron production, possibly involving smithing and smelting, took place close by. This rare instance of iron production on the edge of Mesopotamia serves mostly as a reminder of how little we know about the iron-producing infrastructure of the Assyrian state that generated the massive quantities found at Khorsabad.

\section{Anatolia}

In the broad mountainous arc of Anatolia, the South Caucasus, and Iran, patterns of iron adoption circa 1200-600 BC have received less attention than in the Levant and eastern Mediterranean. This is unfortunate, as Anatolia contains a significant number of iron artifacts dating to the preceding periods (Yalçin 1999). Thus, patterns of iron usage in the late second and early first millennium BC in Anatolia might provide insight into how iron made the transition from rarity to commodity. Assessing 
the Early Iron Age (c. 1200-1000 BC) in Anatolia is challenging, even beyond the scope of metallurgy. In central and eastern Anatolia, there are few well-preserved, undisturbed sites, and similarities of Early Iron Age ceramics to those of both earlier and later periods complicate dating (for a discussion of the issues, see Genz 2003; Köruoğlu 2003; Seeher 2010). Farther west, Aegean ceramic chronologies helped date an important 11th-century BC blacksmith's workshop at Phokaia-one of the earliest workshops with such a complete array of installations and ironworking debris (Yalçin and Özyiğit 2013).

In central Anatolia, a large assemblage of iron was found in the early Phrygian burned layer at Gordion (McClellan 1975, p. 738), which was originally dated to circa $700 \mathrm{BC}$, but sometime in the late ninth century BC now seems more likely (Rose and Darbyshire 2011; Voigt and Hendrickson 2000). Excavations in the Iron Age level of Kaman-Kalehöyük (Stratum II, c. 12th to fourth centuries BC) uncovered increasing quantities of iron artifacts across several subphases, some with parallels to the Gordion material (Masubuchi 2008; Yukushima 2001). By the seventh-sixth centuries BC, iron was very common, as attested by the agricultural implements, nails, and arrowheads found at the short-lived site of Kerkenes (Branting et al. 2017). While the Gordion assemblage indicates extensive use of iron by the ninth century BC in central Anatolia, large, well-contextualized metal assemblages from the crucial 1200-1000 BC period are, with some exceptions (Lehner 2017), lacking.

In eastern Anatolia, graves at Karagündüz are notable for the preponderance of iron artifacts over those made from copper alloys. While radiocarbon assays provide a 12th-century BC date for some of the bones, the ceramic chronology has been questioned by some scholars, who see similarities with pottery found at later sites (Çevik 2008; Köruoğlu 2003; Köruoğlu and Konyar 2008; Sagona and Zimansky 2009, p. 319; Sevin 2003, p. 195). McConchie (2004, pp. 112-113) notes a general paucity of metal artifacts of any kind during this period. The elaborate metallurgical repertoire of Urartu, which challenged Assyria for dominance in the ninth to sixth centuries BC, involved both bronze and iron (Merhav 1991). Surveys of mines and smelting sites have revealed extensive landscapes of silver, copper, and iron exploitation in eastern Anatolia (Belli 1991). While surface ceramic finds may suggest that several of these areas, especially those closest to the Urartian capital at Van (ancient Tušpa), were active during the Urartian period, the extensive reworking of these landscapes in later times is a significant issue (Burney 1996, p. 6; Çifçi 2017, pp. 120, 122). To my knowledge, no radiocarbon dates-either from stratified slag heaps or from inside surface-collected iron slags- have been collected from these sites.

The corpus of Urartian iron artifacts is substantial and varied, showing craftspeople had a high degree of facility with the metal during the ninth/eighth centuries BC (Wartke 1991), However, many unprovenanced Urartian metal artifacts are the products of looting and possibly forgery (Muscarella 2006). McConchie (2004, pp. 185-187), relying on excavated materials, notes different patterns of iron manufacture and use in the Urartian and post-Urartian periods in eastern Anatolia, with iron use in the former period reflecting the demands of a powerful, if somewhat decentralized state. There may have been some kind of state involvement in the 
administration of production, but the precise nature of that control and the extent to which it was exerted over different parts of the production sequence is not as clear (see Çifçi 2017, pp. 119-156; McConchie 2004, pp. 139-141, 185-187).

\section{South Caucasus}

Scholarly understanding of the adoption of iron in the South Caucasus has seen a number of significant adjustments in recent years. The 12th-century BC turmoil, which saw the demise of the eastern Mediterranean palace-dominated exchange systems, did not extend to the South Caucasus. At the same time, the region has a long, if underexplored, history of interaction with other regions of the Near East that provides a common frame of reference. Moreover, the region witnessed a remarkable fluorescence of metal production in the second and first millennia BC that resulted in a substantial record of metal artifacts and production debris through which we can examine metallurgical innovation.

In the southern regions of the South Caucasus (especially the Araxes Valley), the arrival of Urartian armies in the early eighth century BC marked an important development. Still, the effect of Urartian expansion on the adoption of iron use in the South Caucasus is poorly understood. Overall, the impact of Urartian political expansion on the material culture of areas away from nodes of Urartian control seems to have been rather limited (Smith et al. 2009, p. 31). However, if iron production was intimately linked with the Urartian state, perhaps the metallurgical sector of the economy would have been more strongly affected by Urartian expansion. It seems unlikely, however, that iron-making technologies were first introduced by Urartian armies. Traditional chronologies date the appearance of iron in the Middle Kura and Araxes Valleys to the preceding Iron I period (c. 1150-800 BC), prior to Urartian expansion into the southernmost parts of this region (Abramishvili 1957; Badalyan et al. 2009). Although these chronologies are based on few radiocarbon dates and may require adjustment, major redating of the appearance of iron relative to the Urartian period seems unlikely.

Large parts of the South Caucasus were never incorporated into the Urartian state. The nature of sociopolitical organization in these areas is still an open question, in part because the Urartian texts mentioning these areas are brief and rather cryptic (see Khakhutaishvili 1981; Lordkipanidze 1979, p. 48; Melikishvili 1962). The southern and eastern Black Sea area has long been an intriguing locale for scholars of early iron production. Classical texts mention iron production in the area (Apollonius of Rhodes 1971; Pseudo-Aristotle 1936), and the area is known for its ironrich black sands (Tylecote 1981). Beginning in the early 1960s, Georgian archaeologists began to investigate landscapes of metal-smelting sites in the foothills of the eastern Black Sea area (ancient Colchis) (Gzelishvili 1964; Khakhutaishvili 1977, 2009). Hundreds of sites were reported, and nearly 30 were excavated. Radiocarbon and archaeomagnetic dating programs yielded mostly late second and early firstmillennium BC dates, but some reached back to the early second millennium BC (Chelidze 1977; Khakhutaishvili 2009, pp. 105-106). At the time of their discovery, these remains were identified as iron-smelting sites, and some chemical and microstructural analyses were carried out (Inanishvili 2007; Tavadze et al. 1984). In many 
cases, the copper content of the slags is not reported, and it is not possible to correlate published slag microstructures with specific smelting sites. These extremely early dates invited some skepticism, about either the dates themselves or the identification as iron smelting, from both Georgian and foreign scholars (see Mikeladze 1990, p. 52; Veldhuijzen and Rehren 2007, p. 189). A recent comprehensive survey relocating, mapping, and reanalyzing many of these smelting sites has shown conclusively that they are indeed copper-smelting sites (Erb-Satullo et al. 2014, 2015). These new surveys did identify previously unpublished iron-smelting sites, but the earliest dates for these are in the mid-late first millennium BC (Erb-Satullo et al. 2018). Farther east, the site of Kvemo Bolnisi, another suggested early iron production site (Gzelishvili 1964, pp. 31-38), also seems to be connected with copper production (Erb-Satullo 2018).

With the reanalysis of production evidence, scholars must turn to finished artifacts to map patterns of early iron adoption in Colchis. Indeed, extensive Sovietperiod excavations uncovered large quantities of metal artifacts, both copper alloy and iron, from mortuary contexts and hoards (Lordkipanidze 2001; Mikeladze 1985; Mikeladze and Baramidze 1977; Papuashvili 2011; Skakov 2011). There are significant challenges to mapping the appearance of iron with chronological precision, but the available evidence does permit a general picture. Colchian collective graves at Ergeta, Tsaishi, Nigvziani, and elsewhere contain a wide array of bronze objects, including axes, daggers, knives, hoes, "segmented tools" of unclear purpose, billhooks, chains, fibulae, tweezers, figurines, amulets, belt clasps, rings, bells, and torques/bracelets (Apakidze 2009; Papuashvili 2011, 2012; Skakov 2011). Iron artifacts also appear in large quantities in these graves and often parallel the forms of contemporary bronze artifacts. Though reconstructing a precise chronology of collective graves is challenging, most can be dated to the eighth-sixth centuries BC (Papuashvili 2011). In Colchis, at least, the expansion of iron use seems to occur later than in other parts of the Near East.

At the same time, there seems to have been some variability in the patterns of adoption in different areas of the South Caucasus. In the area of modern-day eastern Georgia and Armenia, iron may have appeared somewhat earlier than in the eastern Black Sea area (Abramishvili 1957; Japaridze 1999, pp. 64-65). Unfortunately, dates on the earliest iron artifacts in this region are almost exclusively based on stylistic dating of associated materials, and much of the material remains unpublished (see Akhvlediani 2005, p. 263). Recently, Nieling (2009) has provided a catalog of some early iron finds from eastern Georgia and Armenia as well as eastern Turkey. A significant challenge to tracking the appearance of iron artifacts is the fact that, in the absence of direct radiocarbon dates, the presence and quantity of iron in a grave is used as an important chronological indicator. This method introduces an unfortunate level of circularity if one wants to reconstruct the chronological patterning of iron adoption. Other methods of dating use Near Eastern imports like cylinder seals (e.g., Akhvlediani 2005, p. 289), but one must remember that such items have potential for long-term reuse and represent merely termini post quem. 


\section{Iran}

The chronology for the appearance of iron in Iran is intertwined with larger debates over the Iranian Iron Age chronology, within which the appearance of iron plays only a supporting role. For many years, the definition of the Iron I period was based on broader changes in material culture (especially ceramics) and not on the appearance of iron per se (Pigott 1980, p. 418). Newer chronological revisions have changed the Iron Age terminology. Danti (2013) outlines a new chronology for the LBA (1450-1250 BC), Iron I (1250-1050 BC), and Iron II (1050-800 BC) periods, bringing the Iranian Iron Age periodization more in line with the rest of the Near East and altering earlier designations of Iron I (1450/1350-1100 BC) and Iron II (1100-800/750 BC) (Pigott 1999, pp. 90-91). Nevertheless, this reorganization did not significantly alter the overall picture of iron adoption. Very few iron artifacts are securely dated to the 13th-11th centuries, while significant quantities appeared only in the 11th-9th centuries BC, most prominently at Hasanlu IVb (Danti 2013, pp. 348-352, 356; Pigott 1989, 1999; Thornton and Pigott 2011). A possible ironworker's grave, with raw iron chunks and possible working implements, was identified at Hasanlu and dated to level IVb, based in part on the quantities of iron found in the grave (Danti and Cifarelli 2015, pp. 107-108). Much debate has surrounded the dating of the Hasanlu IVb destruction, most probably at the hands of an Urartian army (see Magee 2008 and references therein), but the earliest proposed date still places it in the late ninth century BC, later than many of early iron assemblages in the Levant.

Some unprovenienced iron swords from Luristan (west-central Iran) have been dated to the 12th-11th centuries BC on the basis of direct radiocarbon dating of the carbon in the iron and the assumption that relatively young wood would have been used for charcoal production (Rehder 1991, pp. 13-14). The technology of their manufacture also has been attributed to an earlier, less practiced phase of ironworking, where working techniques mimic those of bronze (Maxwell-Hyslop and Hodges 1966; Smith 1971). This earlier date has gained wider acceptance (Moorey 1991, pp. 1-2; Pigott 1999, pp. 92-93), superseding earlier suggestions of an eighth-seventhcentury BC date (Muscarella 1989, p. 354). If correct, this would place them among the earliest iron objects in Iran. However, recent research shows that contamination from carbon in steel sampling tools can lead to erroneously old ages (Hüls et al. 2011). In this case, it is difficult to say whether tool carbon contamination might account for the large differences in proposed ages of the swords.

\section{Organizing and Characterizing Iron Adoption Patterns}

In a seminal work, Childe (1944) outlined a model for changes in the use of bronze and iron in Europe and the Near East. He identified two "modes" of iron use as a utilitarian metal. In the earlier mode, iron mimicked bronze artifact types and forms, whereas in the later mode, he found that iron use expanded to new kinds of artifacts. Snodgrass (1980, p. 336) presented a similar model based on three stages, adding 
a first stage corresponding to the period before iron was "used to make functional parts of real cutting and piercing implements." The stage-based models developed by Childe and Snodgrass are the dominant theoretical approach to characterizing changes in iron use in the Near East and the Mediterranean and are frequently referenced in subsequent literature (e.g., Moorey 1999, p. 286; Nieling 2009; Yalçin 1999).

In broad terms, the Childe/Snodgrass model is appealing for its descriptive elegance and its approximation of the main features of the appearance of iron. However, overreliance on stage-based models has several potential drawbacks. Any technological transition can be divided into a beginning (initial stage), middle (transitional stage), and end (final stage), but doing so often obscures underlying variability in adoption processes. The risk of uncritical application of these models is that definitions of the three stages are gradually relaxed and made more generic, until any analytical utility is lost. This is not to suggest that the original formulators ignored nuances and variation in adoption patterns. Snodgrass clearly understood that patterns of metal usage do not always follow linear trajectories, noting that bronze paradoxically became more common in several utilitarian artifact classes from the early to mid-first millennium BC (Snodgrass 1971, p. 228).

However, some generalizations of the model seem less applicable to all regions. For instance, Snodgrass (1980, p. 368) argues that, while technological factors likely stimulated the transition from stage 1 to stage 2, economic factors played the dominant role in the transition from stage 2 to stage 3 . These dynamics may apply to certain regions (e.g., Anatolia and the Levant); in other regions (e.g., Egypt and potentially Colchis) where iron technology was likely known but adopted only after a delay, we must look to social factors to explain resistance to new technologies. Indeed, technological rejection is an underexplored phenomenon that has been documented in studies of early iron use outside the Near East (e.g., Sørensen 1989).

One way forward is to consider different components of the technological transition, one of which is certainly the overall quantities of iron in use as a fraction of the metallurgical assemblage. Changing context of use is another element of the transition, often envisioned as the gradual decline in elite, ceremonial use. Yet another component of the transition might be the initial use of iron for new types of artifacts that have no parallel in the copper alloy repertoire, while a fourth might be the decline of strong parallelisms between iron and copper alloy artifact forms. Childe's (1944, p. 19) model sees these last two as coinciding at the transition between his mode 1 and mode 2, but this may not hold true in all regions. This focus on different elements of the transition facilitates interregional comparison yet avoids the dangers of reductionism inherent in the use of stage-based models.

Keeping these theoretical challenges in mind, several important patterns emerge when we consider iron adoption in different regions of the Near East (Fig. 6). First, extractive iron metallurgy probably began in Anatolia, a supposition supported by both textual and archaeological evidence but nonetheless requiring further confirmation. The Levant and eastern Mediterranean seem to be relatively early adopters, no doubt a result of strong connections between central Anatolia and the Levant during the Late Bronze Age and, perhaps to a lesser extent, into the Iron Age. The adoption of iron in Mesopotamia, northwestern Iran, and the Caucasus seems to have 


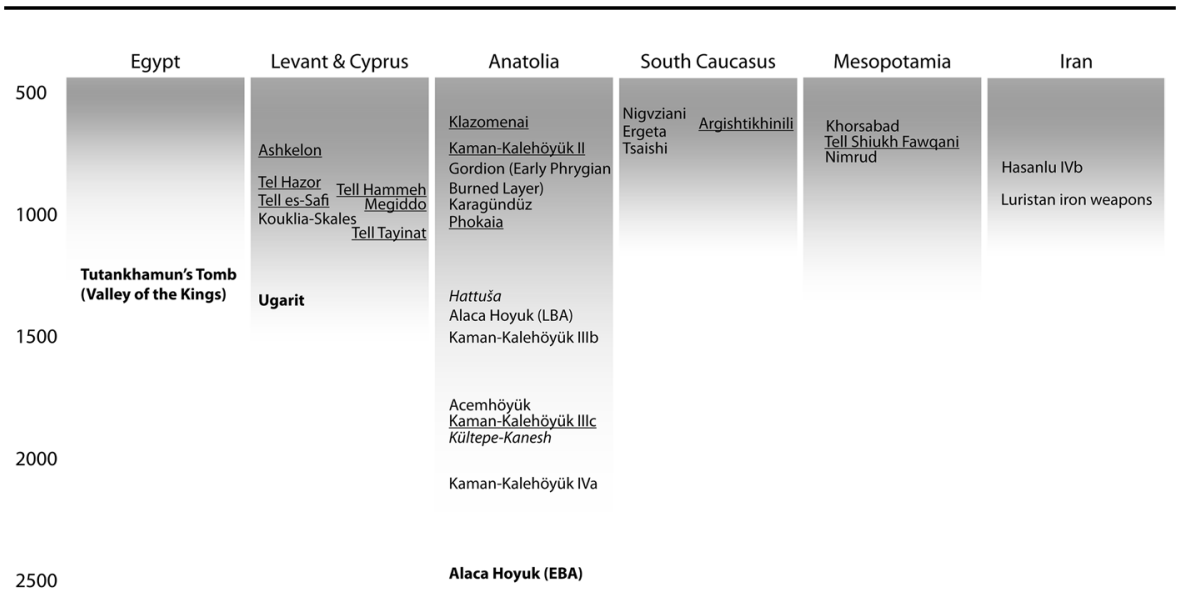

3000

Gerzeh

Fig. 6 Schematic chronological diagram of iron adoption in different regions of the Near East, with selected sites mentioned in the text positioned according to their approximate date. Shading indicates the approximate onset and adoption of extractive iron metallurgy (i.e., smelting) based on current evidence. Sites with iron production debris are underlined, while sites with important texts relating to iron are in italics. Note that italicized or underlined sites may also have iron artifacts. Sites in bold have at least one iron object that has been considered meteoritic in origin

taken place a little later (and in the case of Colchis, significantly later), but we do not have the chronological resolution to state this with certainty. In many regions, the adoption of iron did not represent an abandonment of bronze, and there is strong archaeological evidence that early ironworking and bronzeworking traditions were closely linked (e.g., Eliyahu-Behar et al. 2012; Roames 2011). Interestingly, this evidence runs contrary to texts that distinguish between craftspeople working on iron and bronze (Košak 1986, p. 126). Instead of faltering with the arrival of iron, the contemporary bronze industry often became even more elaborate (Snodgrass 1980, p. 337). To some extent, this observation is at odds with perspectives that seek to explain the rise of iron by contrasting the bronze and iron economies. Rather, the evidence suggests that bronzeworking and ironworking traditions were closely intertwined, and it is quite possible that the same craftspeople were involved in working both metals.

\section{Explaining the Rise of Iron}

\section{Invention}

Explanations for the rise of iron typically consider invention and adoption separately, though it is important to acknowledge that invention is not restricted to beginnings of the adoption process. There is considerable modification or 
adaptation, sometimes called "reinvention," as a technology is adopted, and implementation of one technology can result in a cascade of closely related inventions (Rice and Rogers 1980; Schiffer 2011, pp. 57-60). In the context of this article, the term "invention" does not necessarily involve intentional, directed activities carried out by an individual with a clear goal of solving a clearly defined need. Rather, iron metallurgical technologies (with emphasis on the plural) were likely the result of long-standing experience with the behavior of materials at high temperatures. Some aspects of iron metallurgy may have been the result of intentional experimentation, while others may have resulted from unintended consequences of actions that were only later recognized and replicated.

There are persuasive geological and technological arguments to support the claim that iron-smelting technology emerged from earlier copper-smelting traditions. Geologically, copper and iron ores frequently co-occur. Secondary zones of altered iron oxides, called gossans, often form in the upper reaches of weathered copper sulfide deposits. The geological intermixing of copper and iron-bearing compounds-either through accidental introduction of gangue minerals or intentional addition of a flux to improve slag fluidity - results in an abundance of iron added to the furnace in a copper smelt. Metallic iron, sometimes in excess of $20 \mathrm{wt} \%$, is frequently found in raw copper ingots and as minor phases in copper-smelting slags (Cooke and Ashenbrenner 1975; Craddock and Meeks 1987; Erb-Satullo et al. 2014). Metallurgical experiments show that the reduction of metallic iron is a frequent and sometimes problematic aspect of copper smelting (Rothenberg and Tylecote 1976, p. 236). Some have suggested that the earliest iron may have been produced accidentally in the process of copper or lead smelting (Gale et al. 1990; Shell 1997; Stech-Wheeler et al. 1981, p. 266; Wertime 1964, p. 1262), but supposed examples of artifacts made from that type of iron, found at Timna, have been refuted (Merkel and Barrett 2000). Akanuma recorded higher levels of copper in the interior of iron artifacts relative to the surface at Kaman-Kalehöyük and suggests that the copper was derived from the metal itself rather than contamination. However, some of these artifacts date from the later Iron Age, and the patterns are not always consistent (Akanuma 2006). Microprobe analysis of an iron sulfide inclusion within an Old Assyrian period iron artifact yielded $0.13 \% \mathrm{Cu}$, possibly indicating a link to copper metallurgy (Akanuma 2003, p. 143). Careful microchemical analysis is required to distinguish between diagenetic copper contamination and iron artifacts produced from mixed ores.

Iron "bears," the product of an excessively reducing copper or lead smelt, are occasionally referenced in the archaeometallurgical literature as a possible mechanism for the discovery of iron (Cooke and Ashenbrenner 1975, p. 253). Indeed, corroded lumps interpreted as mixed copper and iron metal have been found at copper-smelting sites in the southern Levant (Ben-Yosef 2010, p. 736), though these fragments have not been systematically analyzed (Ben-Yosef, personal communication, 2016). Even so, a fused mass of iron with a high percentage of copper would have been very hard to process in such a way to make usable iron. The chemical properties of copper and iron are such that it is much easier to remove iron from copper (through preferential oxidation) than it is to remove the copper and leave iron 
metal. Further experimental work is necessary to demonstrate the ability to produce usable iron from a copper smelt.

Yet ancient copper miners and smelters, with their long experience in identifying ores, balancing materials in furnace charges, and driving higher-temperature reduction reactions, were well positioned to invent iron smelting. No other social group besides metalworkers would have had the knowledge and skill to manipulate fire and materials in this way. Attempts to smelt copper-poor, iron-rich ores, either out of necessity as deposits were worked out or through active experimentation, may very well have produced usable iron.

In addition to looking for discarded iron bloom fragments in a copper-smelting refuse dump, a complementary approach would be to identify key elements of copper-smelting practice that could have facilitated the spread of iron smelting. This approach requires careful analysis of copper-smelting technologies before, during, and after the adoption of iron. Craftspeople using copper furnaces that could maintain strong reducing conditions and high temperatures over large reaction volumes would have the technical skills in place to develop consistent iron-smelting practices. Strictly speaking, large reaction volumes are not necessary for the reduction of iron, but it is likely that this feature was important for the consistent production of the quantities of iron that began to appear in the mid-late second millennium BC. At the same time, it is important to avoid shades of technological determinism by recognizing that metallurgical and thermodynamic expertise is perhaps necessary, but certainly not sufficient, for the invention of iron. Direct evidence for the extraction of iron from mixed copper-iron deposits would provide a crucial link between iron and copper production and explain why iron and copper alloy metallurgical practices seem so closely linked during the early periods of iron innovation. This approach shifts effort away from the search for a "moment" of invention toward a more archaeologically recoverable set of practices and behaviors in copper and iron smelting which may have existed for centuries before and after the initial discovery (see approaches in Radivojević 2015; Roberts and Radivojević 2015).

\section{Adoption and Spread}

\section{Material Properties}

In contrast to discussions about the invention of iron smelting, which stress connections between iron and copper alloy metallurgy, explanations for the spread of iron production tend to focus on their differences. The earliest attempts to explain the spread of iron focused on its material properties. Unless it is alloyed with carbon and quenched (rapidly cooled from high temperatures), iron is not significantly harder than a $10 \%$ tin bronze, especially one that has been cold-hammered (Smith 1967, pp. 40-41). Nevertheless, early work took iron's superiority for tools and weapons as fact (Waldbaum 1999, p. 27). Based almost entirely on speculation, early conceptions envisioned iron-wielding invaders having played an integral role in the destruction of Bronze Age palace-based economies (Richardson 1934, pp. 560-561). 
With the maturation of archaeometallurgy as a discipline in the 1960s and 1970s (Smith 1965, 1967), a new suite of studies began to compare early iron's material properties to those of bronze. In particular, much emphasis was placed on identifying the beginnings of carburization (steeling), quenching, and tempering-techniques that make iron unequivocally harder than any bronze. Early iron in the Near East was reduced in solid state, below its melting temperature, a process known as bloomery smelting. Bloomery iron, the first type produced in the Near East, can be carburized through a variety of processes. Iron metal can be heated in close contact with charcoal, leading to the diffusion of carbon into the material (Maddin et al. 1977, pp. 124-126). Bloomery smelting processes also can produce carburized steel directly (Notis et al. 1986, p. 276; Tylecote et al. 1971). By careful selection of materials, forging, and heat treatment, a skilled smith can create a blade with a sharp brittle edge on a softer but more shock-resistant body. On the other hand, prolonged forging can result in decarburization of the surfaces of an artifact. Metallographic analysis can determine whether an iron artifact is iron or steel and identify various heat treatments though the examination of the microstructures. For the purposes of this review, carburization refers to any process by which iron and carbon are alloyed, regardless of intentionality. Yet intentionality, either through selecting more carburized parts of the bloom or by heating iron in contact with charcoal, is a key element of the argument that increased hardness was a key impetus for the adoption of iron.

Two metallurgical features are essential for establishing this intentionality. First, carburization, as evidenced by pearlite and cementite microstructures, should be consistent, both within an artifact and on an assemblage level. Consistency suggests intentionality and the ability to carburize enough of the artifact to make a mechanical difference (McConchie 2004, p. 93; Stech-Wheeler et al. 1981, p. 246). Second, quenching is indicated by the martensite microstructure, which forms only when iron is rapidly cooled from high temperatures. Martensite is particularly desirable on the cutting edges of blades, where increased brittleness is an acceptable trade off. The identification of these microstructures is complicated by the tendency of iron artifacts to corrode. Moreover, an artifact's surfaces and edges, which experience the fastest temperature drops during quenching, are also the first areas to corrode. Thus, vitally important microstructures can easily be lost.

Nevertheless, by the 1980s, enough metallurgical evidence had accumulated for Maddin (1982) to argue that advances in heat treatment were a key element in the rise of iron technology in Cyprus during the 11th century BC. Carburization and quenching are cited in a number of other studies as important developments spurring the rise of iron (McNutt 1990, p. 152; Snodgrass 1971, pp. 214-215). Tholander (1971) identified microstructures consistent with quenching in a knife from Idalion in Cyprus. Maddin's (1982) metallographic study of 51 Cypriot iron artifacts showed that the majority of the artifacts from Lapithos, Idalion, and Amathus, which date to the 11 th and 10th centuries BC, are carburized, whereas a small subset shows evidence of cold working. Two knives from Idalion were likely quenched. Objects from Kouklia-Skales, most of which come from tombs that span the CyproGeometric I (late 11th to 10th century BC) to Cypro-Archaic I (eighth-early seventh century BC) (see Karageorghis 1983 for dating of graves; see Smith 2009, pp. xviixviii for a revised Iron Age chronology), show a mixture of carburization regimes, 
with some examples showing extensive carburization while others show none. No evidence of quenching is reported. At Kition, three examples from 11th-10th-century deposits show some carburization, but the majority of the artifacts from the later Phoenician, Archaic, and Classical periods do not. This pattern is somewhat at odds with the argument that carburization and heat treatment were regular features of Early Iron Age Cypriot iron technology. Moreover, McConchie (2004, pp. 31-33) questions the interpretation of some of the metallographic microstructures, arguing that the evidence for quenching in the Idalion knives should be reexamined.

Detailed metallographic analyses have also been carried out on iron artifacts from the southern Levant to assess the possible role of carburization and heat treatment on the spread of early iron. Stech-Wheeler et al. (1981) conducted a large-scale metallographic analysis of artifacts from Taanach and other early first-millennium southern Levantine sites. Many of the artifacts show evidence of consistent carburization, but a significant portion of the assemblage does not, and the study revealed no evidence of quenching and tempering. A pick with minimal corrosion from Mt. Adir was thought to show evidence of the 12th-century BC practice of carburization, quenching, and tempering (Davis et al. 1985), but new evidence suggests that the artifact dates to the second century BC (Yahalom-Mack and Eliyahu-Behar 2015, p. 297n). McConchie (2004, p. 20) discounts the presence of carburization alone as evidence that the discovery of iron's superior mechanical properties was a major feature in its supplanting of bronze, pointing out that "alloyed iron (steel) alone did not produce revolutionary improvement in terms of hardness." Recent work in the southern Levant confirms the overall perception that metalworkers did produce ironcarbon alloys, but most are low in carbon $(<0.3 \% \mathrm{C})$, so this was probably not an intentional effort to maximize hardness (Eliyahu-Behar and Yahalom-Mack 2018; Yahalom-Mack and Eliyahu-Behar 2015, p. 297).

Due to the efforts of Stech-Wheeler, Maddin, and others, the eastern Mediterranean and Levant have the largest dataset of metallographic analyses on iron. However, several other studies offer glimpses of manufacturing techniques and alloy compositions in other regions. Three late eighth-century BC Assyrian iron artifacts from Khorsabad, including an adze, a hoe, and an iron ingot, were analyzed by Pleiner (1979). The hoe and the adze both showed minimal evidence of carburization, while the ingot is heavily carburized, consisting of mostly pearlite. Due to the lack of carburization in other objects, Pleiner suggests that it may have been unintentional (Pleiner 1979, p. 90). Further analysis of two ingots from Khorsabad and two from Nimrud shows significant variation between samples (Curtis et al. 1979). Metallographic examination of eight finished objects from Nimrud, conducted as part of same study, shows more consistent evidence of carburization, though not of quenching or tempering.

Metallographic investigations for western Iran come primarily from two groups of iron artifacts - those excavated at Hasanlu, and weapons from Luristan that lack secure contexts. Pigott (1981, pp. 139-145, Appendix A) analyzed 10 artifacts from Hasanlu. While some carburization is present, he argues that it was not deliberate and controlled (Pigott 1981, p. 144). Metallographic analyses of swords from Luristan show that they were made from inconsistently carburized iron and were fashioned using techniques, such as riveting and crimping, that are most suited 
to bronze rather than iron (Maxwell-Hyslop and Hodges 1966; Pigott 1981, pp. 175-180; Smith 1971).

The most comprehensive metallographic study of early Anatolian iron production is McConchie's (2004) study of artifacts from Sos Höyük, Büyüktepe Höyük, Van Kale, Ayanis, and Karagündüz. The sampled objects span the early first millennium to the post Achaemenid period (McConchie 2004, pp. 91-93). The earliest iron artifact, from ninth-century BC Karagündüz, shows some carburization, though McConchie (2004, pp. 123-124) does not interpret this as intentional. Seventh-sixth century BC iron artifacts demonstrate a slight tendency toward carburization for edged objects, but McConchie (2004, p. 137) concludes that technical improvements in hardness were not strongly correlated with the expansion of iron use. A slightly different perspective is provided by Masubuchi's (2008) analysis of seven arrowheads from various Iron Age levels at Kaman-Kalehöyük, which she argues show evidence of intentional carburization in the early first millennium BC. Unfortunately, the sample size makes inferences about the consistency of this technique, if it is indeed intentional, difficult. Publication of Masubuchi's recent $\mathrm{PhD}$ dissertation (2016) should clarify some of these issues.

Overall the evidence that the pursuit of harder metals led to the replacement of bronze by iron is ambiguous. Some early studies note an apparent east-west contrast in the frequency of carburization (Pigott 1981, p. 144; Pleiner 1979, p. 91), but this apparent pattern may be due to the varying intensity of work in different regions. Because of the difficulties of identifying intentional carburization, the relatively small corpus of analyses, and the severe problems of corrosion, scholars differ on the role of hardness and carburization in the spread of iron. In these discussions, it is important to distinguish between the distinct, yet related issues of whether ironworkers were making iron artifacts that were harder than bronze, whether these hardness differences were large enough and consistent enough that they were noticeable, and whether hardness was desirable and intentionally selected for as material property. The first issue is more easily assessed by metallographic analysis and microhardness testing, but the latter two are crucial if one is trying to make an argument that intentional carburization, quenching, and tempering were key "tipping point" innovations that lead to the spread of iron.

Given the problems that surface corrosion poses for identifying quenching microstructures, it is likely that the final resolution of this issue will prove elusive for some time. Relatively recent papers still raise the discovery of steeling as the key factor in the spread of iron (Muhly 2003, pp. 180-181), but given the current evidence, it is hard to argue that it served as the major factor that lead to the spread of iron. A large program of hardness testing on an assemblage containing both bronze and iron would help clarify whether, given the variability in both iron and copper alloys, categorical differences in hardness would have even been appreciable to the ancient smith. Unfortunately, heavy corrosion of many iron artifacts means that hardness testing is difficult, even if small amounts of metal are preserved (EliyahuBehar and Yahalom-Mack 2018, p. 448).

Methods for consistently increasing the hardness of iron may have been a consequence of the widespread use of iron, rather than its initial impetus. Among possible late second-millennium BC technological innovations that impacted early iron 
adoption, innovations in smelting technologies that led to larger and more consistent iron yields are more likely candidates for "tipping point" innovations. More generally, however, identifying key technical developments provides only a partial explanation for why iron spread. To fully understand iron adoption, one must have a sound understanding of the social conditions that drove these processes.

\section{Economic Explanations}

The second set of explanations for the rise of iron focuses on the organization and economics of iron production relative to bronze. Technological and economic explanations should not be considered mutually exclusive; many discussions mention both (McNutt 1990, pp. 148-154; Veldhuijzen 2012, p. 238).

At the root of these economic explanations for the rise of iron is a fundamental geological fact. Iron is far more common in the earth's crust than copper and its common alloying elements. The average elemental abundance of copper is approximately 50 ppm, compared with 54,000 ppm for iron (Krauskopf 1979, pp. 544-545). Of course, iron is present in a number of rocks and minerals that are totally unsuitable for preindustrial iron smelting. Nevertheless, the overall pattern holds: usable iron deposits are more common than usable copper and tin deposits. Very early on, scholars began to recognize this difference and its potential importance for the spread of iron technology. Engels (1902, p. 197) referenced the twin advantages of ubiquity and hardness of iron as key factors in its adoption on a large scale. Childe (1944, p. 20) praised the "universal availability of cheap and efficient iron tools" as a key social development with major social and economic impact and argued that they were instrumental in land clearance, agricultural extensification, and population expansion (Childe 1951, p. 180). These arguments laid the groundwork for the conception of iron as the "democratic metal" so often mentioned in later works (e.g., Horne 1982, p. 12).

A new line of reasoning began to take shape in the middle of the 20th century, which posited that the ubiquity of iron ore was the major impetus for its initial adoption. Scholars hypothesized that the collapse of regional trade networks at the end of the Bronze Age cut off supplies of tin and copper, the key ingredients to make bronze. In the Late Bronze Age, Cyprus was the preeminent supplier of copper for the eastern Mediterranean, while tin could have come from a number of sources as far away as Central Asia (e.g., Boroffka et al. 2002; Crawford 1974; Erb-Satullo et al. 2015; Garner 2015; Nezafati et al. 2009; Stöllner et al. 2011; Yener et al. 1989, 2015). Following the breakdown of these key trade routes, local smiths had to search for a new metal with which to make their tools (Maddin et al. 1977, p. 122).

Snodgrass (1971) presented the earliest argument for a copper and tin shortage driving the rise of iron, using archaeological evidence from Greece. He pointed to a decline in bronze between 1025 and $950 \mathrm{BC}$ and argued for a correlation between the decline in Greek-Cypriot contact and the expansion in iron use (Snodgrass 1971, pp. 237-238, 248-249). For the subsequent 20 years, a tin and/or copper shortage was frequently referenced as a likely cause of the rise of iron not just for Greece but also for the wider eastern Mediterranean (Maddin et al. 1977; McNutt 1990, pp. 153-154; Muhly 1980, p. 47; Waldbaum 1980, p. 83). In the more expanded 
perspective, the timing and duration of this rather hazy tin or copper shortage was never well defined, but the general sense was that it coincided with the so-called 12th-century BC collapse of the LBA palace system.

At first glance, there is much to recommend the idea of a raw materials shortage. Archaeological sites around the region show signs of disruption, and evidence suggests that these disruptions resulted in the movement of people (Liverani 1987). Traditional powers of the Late Bronze Age either ceased to exist or experienced periods of retraction. The elaborate pageantry of royal gift exchange (Feldman 2006), which resulted in the transfer of significant quantities of both raw materials and finished goods, broke down. An intriguing text from Pylos recounts the collection of a relatively small amount of temple bronze for remelting into weaponry. Some interpreted this text as evidence for recycling due to an extreme shortage, in which all available bronze, including the ritual accouterments of a temple, was remelted for essential military equipment (Hooker 1982).

Despite its seeming appeal, the tin and copper shortage hypothesis lacks a strong foundation in the archaeological record. From the early 1990s, the theory came increasingly under fire. Indeed, some of the original adherents of the resource shortage hypothesis were among those who made the greatest efforts to set the record straight. In contrast to his earlier work, Muhly (1992a, p. 17, 1992b, p. 701) argued against a shortage of copper during the 13th and 12th centuries BC. On the contrary, the Cypriot copper industry seems to have expanded during this period. The large number of copper alloy artifacts from 12th-century Cyprus has several other interpretations, including a relative increase in local consumption of Cypriot copper (Papasavvas 2012), or possibly a practice of 12th-century looting of earlier 13th-14th-century graves (Karageorghis and Kassianidou 1999, p. 172). Although the number of bronze artifacts found in Cypriot contexts dating to the 12th century is greater than in the previous centuries, this does not necessarily indicate a complete reorientation of copper production toward a local market. In fact, there is evidence to suggest that Cypriot trade expanded during this period, with new markets opened in the central and western Mediterranean while contacts were maintained with the Levantine and Egyptian worlds (Muhly 1992a, p. 19). Recent work also suggests continuation of copper production from the 11th to eighth centuries BC (Charalambous et al. 2014; Kassianidou 2014). Farther afield, an Early Iron Age (1200-1100 BC) workshop at Hattuša also supports the idea that metal production and exchange continued in some form during this period (Lehner 2017).

Muhly reinterpreted the text from Pylos, arguing that the reference is to "ship copper" rather than "temple bronze." On this basis, he argued not only that the text contains no reference to stripping temple equipment, but also that it shows the trade in raw copper was still active (Muhly 1992a, p. 18). Evidence for a shortage of tin during this period is also problematic, since there is no evidence for a decline in the tin content of bronzes in Greece, Cyprus, and the southern Levant (Waldbaum 1999, p. 39).

Reconsideration of resource shortage hypotheses formed part of a growing reevaluation of the collapse of Late Bronze Age empires, which has noted some elements of continuity in this period of reorganization (e.g., Harrison 2009, p. 187). In light of these reconsiderations, scholars argued that although the palace-based 
economies of the Late Bronze Age did falter during this period, they were replaced by new systems of trade and exchange (Muhly 1992a; Sherratt 1998).

Readjustment of trade routes and changes in political dynamics may indeed have resulted in small-scale shortages (Mirau 1997, p. 105), which would have figured in the short-term decisions of craftsmen. However, brief episodic shortages of copper and tin may be archaeologically invisible. Such shortages were probably a regular occurrence, even during the height of the Late Bronze Age economic system. Annual campaigns of great kings often destroyed cities and probably disrupted the metal supply at times. Textual evidence from the Late Bronze Age recounts the complaints of one ruler to one another about delayed or insufficient shipments of goods (Liverani 2008, pp. 166-167). Conversely, looting and tribute collection was a key source of metal wealth, so times of conflict are not necessarily times of scarcity for all.

Despite major critiques of the shortage hypothesis, the concept that the relative availability of copper, tin, and iron played a role in the rise of iron has had remarkable staying power. Recent papers still cite a tin shortage as one of several plausible factors in the adoption of iron (e.g., Veldhuijzen 2012, p. 238). While this reevaluation pushed some scholars to place more reliance on the material properties explanations (Muhly 2003, pp. 180-181; Pickles 1988, pp. 22-24), other scholars emphasized organizational aspects of iron production that made it more attractive than bronze production. These later formulations still rely on the fundamental geological fact of iron's ubiquity relative to copper and tin. However, instead of positing a "push" model in which metal-producing communities were forced to search for an alternative to bronze, they argue for a "pull" model in which locally available iron allowed newly formed polities to decrease their reliance on foreign trade.

This change in perspective is effectively encapsulated by Mirau's examination of the social and political context of iron adoption in the Levant (Mirau 1997). He unequivocally rejects the bronze shortage hypothesis (Mirau 1997, p. 105), yet his ultimate explanation for iron's spread rests on the same foundations as this earlier theory: the spatial distribution of raw materials and the relative organization of iron and bronze production. The Levant saw a decentralization of political power, in which local elites were less closely tied with regional empires, allowing them to take advantage of new, locally available resources. As with earlier theories, smaller innovative polities using local metal sources are contrasted to larger, highly interdependent systems of imperial exchange reliant on the movement of metal over long distances (Mirau 1997, p. 111). Mirau argues that, combined with demographic expansion and increasing demand for metal in general, iron was an attractive alternative to bronze. If the tin/copper shortage hypothesis represents a push model, new perspectives that took root in the middle 1990s can be seen as a pull model, but the underlying principles are the same.

There is much to recommend this revised perspective, at least for the southern Levant and, perhaps, the wider eastern Mediterranean. Most importantly, it connects the rise of iron with social and demographic processes that occurred continuously during the long period in which iron grew in frequency. Close attention to the economic and political conditions is essential for explaining the adoption process. In some areas, at least, early iron initially may have served more as an 
addition to an expanding metal economy, rather than as a replacement for bronze (e.g., Papuashvili 2012; Yahalom-Mack et al. 2017, p. 70). These patterns would explain why iron continued to grow in prominence even as Wadi Arabah emerged as a major copper supplier in the Early Iron Age (Ben-Yosef et al. Ben-Yosef et al. 2010a, 2010b, 2012; Levy et al. 2012).

A less-discussed theory for the spread of iron that also falls under the category of resource availability concerns the relative fuel consumption requirements. The intensive fuel demands of metallurgical activities are well documented in Near Eastern contexts, especially in arid regions (e.g., Hunt et al. 2007; Wertime 1983). It has been suggested that iron metallurgy required far less fuel than copper metallurgy, and that this might have been a factor in its adoption (Horne 1982 , p. 12). However, fuel input:metal output ratios for smelting vary considerably (e.g., Tylecote et al. 1971, p. 354), and the relative fuel consumption would depend on a number of difficult-to-estimate variables. Fuel efficiency considerations, therefore, seem unlikely to have driven the transition to iron (Waldbaum 1999, pp. 42-43).

Following the reevaluation of the tin shortage hypothesis, some argued that research on the innovation of iron had stagnated, hampered primarily by a lack of data on the places where early iron was made (Veldhuijzen 2012, p. 246). Situating the metallurgical systems of iron and bronze within their broader social context represents an important way forward. In these endeavors, the examination of production contexts-workshops, smelting sites, and mines-is of fundamental importance to evaluating theories about the spread of iron. Fortunately, recent research has produced new data on Late Bronze and Early Iron Age metal production contexts, allowing scholars to begin to address these issues. It should be stressed that both iron and copper alloy metallurgy must be considered in this regard; it is impossible to consider innovations in iron metallurgy without considering contemporary developments in the manufacture and exchange of copper and bronze. Thus, in the following section I discuss the current state of knowledge about the relative organization and patterning of both copper alloy and iron production. As before, the Levant remains a focus of research, providing detail unavailable elsewhere, but new work in the mountainous margins of the Near Eastern world has begun to provide valuable comparative data.

\section{The Social Context and Organization of the Metal Economy}

Thanks to new work in the last 15 years, scholarly understanding of copper and iron production in the Levant and eastern Mediterranean is becoming clearer. With an increase in the investigation of workshops and production debris, scholars may now begin testing hypotheses that tie the spread of iron to relative differences in the social organization of iron and copper alloy metallurgy. Here, I discuss evidence from metal production workshops and what they reveal about the relative organization of the bronze and iron economies. 


\section{Iron Metallurgy}

The most complete assemblage of iron-smelting debris, found at Tell Hammeh in central Jordan, has been radiocarbon dated to the 10th-ninth century BC. Excavations, combined with extensive chemical and microscopic analysis, have provided a virtually unparalleled example of how iron production was organized during this period (Veldhuijzen 2009a, 2012; Veldhuijzen and Rehren 2007). Iron-smelting activities occurred during a roughly 100 -year phase when there was little evidence of permanent settlement on the mound, at least in the excavated areas. The excavators hypothesize that iron smelting was carried out seasonally, using ore from the nearby Mugharet el-Warda source (see also Alamri and Hauptmann 2013). Veldhuijzen and Rehren (2007, p. 193) estimate that the approximate total annual output of these furnaces was in the order of $50-100 \mathrm{~kg}$ of iron per year over 100 years. The total ore processed is estimated at about $100-200 \mathrm{~kg}$ per year. These results are consistent with seasonal smelting. Although the authors are rightly reluctant to make any sweeping conclusions about the socioeconomic context in which iron production occurred (Veldhuijzen and Rehren 2007, p. 193), the evidence suggests that smelters were not closely tied to political elites. Admittedly, Tell Hammeh, with such a large and complete assemblage of iron-smelting debris, is virtually unique, making it difficult to generalize. However, the nature of production contrasts markedly with contemporary Levantine copper production (e.g., Levy et al. 2014b) and is consistent with a model of local, small-scale iron-making enterprises (Veldhuijzen and Rehren 2007, p. 199).

In addition to Tell Hammeh, there are tantalizing hints that iron smelting took place in or near urban contexts in the southern Levant (Eliyahu-Behar et al. 2012, 2013; Erb-Satullo and Walton 2017; Yahalom-Mack and Eliyahu-Behar 2015; Yahalom-Mack et al. 2014a). The case for iron smelting at a large urban site was first made for an Iron IIA (late 10th-ninth century BC) workshop at Tell es-Safi (Eliyahu-Behar et al. 2012). The case for smelting, as opposed to smithing, was based on the macromorphology and chemistry of the slag. No metallic iron was reported in the Tell es-Safi slag, which is somewhat odd given that smelting slags (especially those that were not tapped from a furnace) often contain small aggregates of reduced iron that did not coalesce into the bloom. Moreover, while some have noted mineralogical and chemical differences between smelting and secondary working slags (Gordon 1997), there is substantial variability, depending on the richness of the ore and other additions to the furnace charge. Distinguishing between smithing and the proposed non-tapping smelting process involving very rich ores and producing little slag is challenging, even with microstructural and chemical evidence. A later paper by the same group presented a more convincing case for smelting, including a possible ore fragment, several bloom fragments, and a slag cake with metallic iron (Eliyahu-Behar et al. 2013). At Tell Shiukh Fawqani (Luciani 2016; Luciani et al. 2003), potential tap slags and partially reacted magnetite grains in the slag (suggesting that the magnetite was a primary addition to the melt) may also indicate smelting. Still, recent ethno-metallurgical work in Africa has shown that smithing slags can contain significant quantities of 
metallic iron, and that some smithing hearths can even achieve conditions necessary to reduce iron oxides to iron metal (Soulignac 2017).

Analysis of iron production debris from Iron Age Ashkelon (mostly from eighthcentury BC contexts) identified slags with metallic iron, several pieces of tap slag, and what appears to be partially reacted ore in the process of being reduced to iron metal (Erb-Satullo and Walton 2017). Even if some of the partially reduced ore microstructures from Ashkelon are somehow the result of iron oxides (e.g., hammerscale fallen into the hearth) being reduced in a smithing hearth as an unintentional, accessory process, the tap slags are more diagnostic of smelting. Although the evidence at Tell es-Safi is somewhat equivocal, these later results put the argument for smelting at or near these urban centers on a stronger footing. Nevertheless, based on the current evidence, it is still too early to make the claim (Yahalom-Mack and Eliyahu-Behar 2015, pp. 300-301) that multiple distinct iron-smelting technologies existed in this region during the Iron II period. Urban assemblages of production debris are likely to be affected by the cleaning of workshop spaces and localized redepositing of debris. Therefore, one must be cautious when comparing smelting technologies at sites affected by different taphonomic processes.

Evidence for secondary iron production appears at a number of sites spread across the Levant (Eliyahu-Behar et al. 2008, 2012; Erb-Satullo and Walton 2017; Roames 2011; Veldhuijzen 2009b, c; Veldhuijzen and Rehren 2007). A major archaeological signature of smithing is hammerscale: small flakes of oxidized iron that detach from the iron metal during smithing. Because these small fragments are magnetic, they can be separated out from the surrounding soil with a magnet. Sometimes, flakes of hammerscale become trapped in slags, where they are preserved as oblong platy or tabular clusters of iron oxides (Erb-Satullo and Walton 2017, p. 14). Distinctively shaped slag cakes, known as smithing hearth bottoms, are also characteristic of smithing activities, formed by the collection of slag in a smithing hearth. Finegrained excavation techniques can produce a map of hammerscale distributions, as demonstrated in the circa 900 cal BC stratum at Tel Beth Shemesh (Veldhuijzen 2009c; Veldhuijzen and Rehren 2007, pp. 196-198). Regardless of the interpretation of the larger slag piece, the presence of hammerscale in the Tell es-Safi workshop confirms that iron smithing took place there (Eliyahu-Behar et al. 2012).

Additional evidence of smithing comes from an Iron I (12th/11th century BC) context at Tell Tayinat in southeastern Turkey (Roames 2011). Published analyses are preliminary, but the available evidence suggests that both copperworking and ironworking took place. The presence of several smithing hearth bottoms and hammerscale is diagnostic of iron smithing. At eighth-century BC Ashkelon, magnetitedominated slags - indicative of much more oxidizing conditions than those interpreted as smelting slags-attest to smithing at this site as well (Erb-Satullo and Walton 2017, pp. 12,14). Somewhat later evidence of smithing activities includes debris from a seventh-century BC rubbish pit at Tel Dor (Eliyahu-Behar et al. 2008) and a smithy at Tel esh-Shari'a in the Negev with a terminus post quem of the late seventh to early sixth century BC (Rothenberg and Tylecote 1991). A small accumulation of slag in close association with a stone mortar at the sanctuary of Khirbat al Mudayna has also been interpreted as smithing debris. To this list can be added a handful of unpublished instances of Levantine iron smithing reported as personal 
communications by Veldhuijzen and Rehren (2007, p. 191). The recent increase in information about southern Levantine iron production is the direct result of the efforts by archaeometallurgical specialists to investigate ephemeral residues that might otherwise escape notice in a large urban excavation. While the identification of different stages of the chaîne opératoire, the delineation of different technological traditions, and the interpretation of social context are in some cases up for debate, there is no question that these studies are crucial to our understanding of iron innovation in the area. Ongoing work on southern Levantine production contexts and metal assemblages (e.g., Eliyahu-Behar and Yahalom-Mack 2018; Yahalom-Mack et al. 2017) promises to shed further light on the question of where and when iron production took place in this region.

Detailed contextual information is not always available, but it is clear from the much larger number of smithing examples that iron smithing was frequently carried out in settlements. At Tel esh-Shari'a, smithing activities within the citadel indicates a degree of control over production. Veldhuijzen (2012) suggests that this might represent a change in the pattern of iron production during the Assyrian period, when the state asserted control over production. However, the association between institutions and iron production is not restricted to the period of Assyrian domination. The metal workshop at Tell es-Safi was found in close proximity to several structures related to cultic activity. The stratigraphic situation is complex, and there is no direct association between metal production and possible ritual spaces, but Eliyahu-Behar et al. (2012, pp. 256-257) suggest that cultic activities may have been carried out contemporaneously with metal production. Still, the ways in which spatial relations between workshop areas and institutional structures correspond with social relations between craftspeople and elites are complex. One should be wary of overly simplistic correlations between proximity and control.

Outside the eastern Mediterranean, direct evidence for iron production of any kind is sparse, making it more difficult to make inferences about the social context in which it occurred. Although scattered iron production debris has been found in a wide range of second and first-millennium BC contexts at Kaman-Kalehöyük, the site lacks clearly defined iron workshop areas (Akanuma 2001, 2002, 2007). Two blacksmiths' workshops on the Aegean coast of Anatolia were identified at Phokaia (11th century BC) (Yalçin and Özyiğit 2013) and at Klazomenai (Archaic period) (Cevizoğlu and Yalçin 2012).

As discussed above, the metallurgical landscapes of the late second and early first millennium BC on the eastern Black Sea region relate to copper rather than iron production. While the presence of iron objects suggests that local production occurred earlier, the earliest dates for iron-smelting sites in this area are in the mid-late first millennium BC (Erb-Satullo et al. 2018). Mining and smelting landscapes mapped by Belli (1991) in eastern Anatolia may date to the early first millennium BC, but caution is warranted, given the issues of later exploitation and the lack of radiocarbon dates.

The discovery of metallurgical debris in the western citadel of Argishtikhinili is particularly intriguing with respect to the social context of metal production during the Urartian period (Martirosyan 1974, pp. 95-97, 150-157). Microstructures of slags and other production debris were not published, so it is difficult to say 
exactly what metallurgical processes took place there. However, it seems probable, given the finds of a hearth/furnace, green-flecked crucibles, slags, and reported iron blooms, that both copper alloys and iron were worked there. The relationship of this workshop to Urartian authorities at the site is unclear, however, as the "House of the Metalworker," where these items were found, was constructed so that it blocked the fortress's main eastern entrance, implying what the excavator referred to as the negligence or mismanagement ("beskhozyaystvennost") of the fortress in the seventh century BC (Martirosyan 1974, pp. 96, 150-157).

In the Urartian levels at Horom, excavators report "iron nodules," a piece of slag, and a spearhead in one room, but no scientific analysis of these finds is reported (Badaljan et al. 1993, p. 17; see also McConchie 2004, p. 121). It is unclear whether the nodules were heavily corroded artifacts, bits of bloom, or possibly even fragments of ore. Without chemical or microstructural analysis of the slag, it is impossible to identify conclusively what kinds of metal production were taking place here.

\section{Copper and Copper Alloy Metallurgy}

Though it might seem out of place to discuss copper and bronze production in a review on iron innovation, the two are inextricably linked. Implicit or explicit in any discussion of iron adoption is a comparison of the technology, organization, and distribution of copper alloys and those of iron. While details about copper production and trade in LBA eastern Mediterranean is still under discussion, the prevailing view is that much copper production and trade was organized and managed by elites, though not always by the state (Bell 2012; Liverani 2003). The view that the longdistance copper and tin trades were strongly integrated with palace-based regional hegemons is an integral part of arguments that explain the rise of iron as a consequence of the Late Bronze Age collapse (e.g., Sherratt 2000). It is worthwhile, therefore, to discuss what is known about the organization of the bronze industry on both sides of the Bronze Age-Iron Age transition.

A massive copper industry existed on Cyprus in the Late Bronze Age. Bronze Age texts name Alashiya-meaning either Cyprus as a whole or a part of it (see Goren et al. 2003) _ as a main supplier of copper in the LBA eastern Mediterranean. Shipwrecks such as Uluburun (Pulak 1998, 2008) provide archaeological corroboration for textual accounts of a vigorous trade in metals and other luxury goods across the Mediterranean. The geological basis for Cypriot dominance of the LBA copper trade was the major copper sulfide deposits of the Troodos ophiolite complex (Constantinou 2012). One of the earliest applications of lead isotope analysis to archaeological copper sourcing identified Cyprus as the main producer of the so-called oxhide ingots, which have been found across the Mediterranean (Gale 1999; Gale and Stos-Gale 1982; 2012; Stos-Gale et al. 1997). Cypriot copper sources were at the center of methodological debates about the application of lead isotopes to archaeological materials (for a recent summary, see Pollard 2009). While it is generally accepted that most, though perhaps not all (see Ben-Yosef 2012; Lagarce 1983), of the oxhide ingots are made from Cypriot 
copper, there is still significant disagreement over which mines were exploited at which times (Gale and Stos-Gale 2012; Knapp 2012; Stos-Gale et al. 1997).

Copper production debris found on Cyprus provides some indication of the industry's organization. Located near a major ore deposit, the Late Bronze Age (roughly 13th century BC) remains at Apliki-Karamallos consist of several structures, some of which are interpreted as storage facilities for supplying a workforce engaged in metallurgical production. Metallurgical activity is clearly demonstrated by the presence of slag and tuyères. Analysis of the metallurgical remains has not been published, however (Knapp 2012, pp. 20-21), and the question of elite oversight of mining and smelting activities is difficult to resolve. The discovery of a gold earring at the site (Knapp 2012, p. 20) hints at enmeshment in a wider economic network, perhaps with elite oversight, though one should be careful not to overinterpret this single find. Aside from Apliki, the small smelting site of Politiko-Phorades offers the only other example of LBA metallurgical activity in the immediate vicinity of Cypriot copper deposits (Kassianidou 1999; Knapp and Kassianidou 2008; Knapp et al. 2001). The site dates to the 16th-15th centuries BC (Knapp and Kassianidou 2008, pp. 139-140), so it is difficult to say whether the site is representative of later production in the 14th-12th centuries $\mathrm{BC}$, when Cypriot copper production reached its zenith.

Copper production debris has been found at a number of settlements across the island (Courtois 1982; Doonan et al. 2012; Kassianidou 2012; South 2012; Stech 1982; Tylecote 1982). The exact spatial organization of different stages of the chaîne opératoire is not entirely clear, however. Some scholars propose that initial stages of smelting were carried out at sites like Politiko-Phorades, while the final stages of matte roasting and copper metal smelting were carried out at coastal settlements (Knapp and Kassianidou 2008; but see Tylecote 1982).

There is substantial archaeological evidence to suggest elite participation in copper production, though the evidence for exclusive state control is far weaker. Metalworking at Enkomi is found in multiple phases of a large building referred to as a fortress (Kassianidou 2012). Yet it is also clear that copper production was carried out in numerous locations around the city (Courtois 1982). At the site of Kalavasos-Ayios Dhmitrios, smelting debris was found in several places, though not in the large administrative building there (South 2012). Of course, spatial proximity and control are not perfectly correlated, a factor that must be considered when we assess how spatial relations map to social ones. Dirty, smelly, metallurgical activities may not have been welcome near a seat of power. Nevertheless, the evidence does indicate that copper production at urban Cypriot sites was not spatially centralized in a few large workshops, perhaps indicating production by different social groups. The Cypriot mode of organization contrasts with the large bronze-melting workshop at Pi-Ramesse in Egypt, which had several banks of melting furnaces arranged in rows situated in a large industrial complex that was clearly designed to support the needs of the pharaoh and his building projects (Rademakers et al. 2017; Rehren et al. 1998, pp. 230-231). These comparisons provide an important reminder that the relationship between the bronze industry and institutions of political authority may have varied even within the eastern Mediterranean sphere. 
With regard to the long-distance trade in copper and bronze, scholars have debated the degree to which merchants acted independently or were attached to Late Bronze Age palaces (Knapp 1993, pp. 338-340; Liverani 2003; Routledge and McGeough 2009; Sherratt 2000). Textual evidence makes it clear that the movement of material was substantial and that large-scale shipments were relatively common (Bell 2012). This lends support to the characterization of LBA copper trade as a large-scale, well-organized industry under some kind of elite supervision.

With the onset of the Iron Age, there were elements of continuity and transformation in the bronze economy. The copper alloy scrap in the cargo of the circa 1200 BC Cape Gelidonya wreck has been offered as a counterpoint to the earlier ingotdominated metal cargo of the Uluburun shipwreck, suggesting a changing metals trade (Sherratt 2000, pp. 87-88). On Cyprus, copper production declined in the 11th century BC, though this may be due to a lack of excavated 11th-century BC settlement contexts, which are obscured beneath later Iron Age cities (Kassianidou 2014). Indeed, analysis of metal artifacts suggests a continuous input of fresh metal-both copper and tin-into the metal economy of the island in the 11th to eighth centuries BC (Charalambous 2016; Charalambous et al. 2014).

In the southern Levant, the scale and concentration of production in the Arabah increased, corresponding with other evidence for the centralized administration of copper smelting. The walled smelting camp at Timna Site 30 was once considered an archetypal Late Bronze Age Egyptian mining camp (Rothenberg 1990, pp. 8-12), but recent investigations have redated this site to the Iron Age (Ben-Yosef 2010, p. 567). This redating has placed large-scale Early Iron Age mining activities at Timna in line with the even larger Iron Age smelting complex on the other side of the Wadi Arabah. The largest of these Iron Age copper-smelting camps, Khirbet en-Nahas, shows all the trappings of a highly organized, large-scale enterprise: approximately 50,000-60,000 tons of slag concentrated in a single 10-ha site, with building complexes and a large square fort (Levy et al. 2014b). Excavators hypothesize that the expansion of copper production in the late second millennium BC was an essential element of Edomite state formation (Levy et al. 2004). In this sense, these sites fit with the narrative that Levantine Iron Age states sought to exert control over local resources as they vied for power following the contraction of Egyptian and Hittite imperial authority. Indeed, recent research on copper ingots from the southern Levantine coast effectively captures the shift from Cypriot copper sources to those of the Arabah (Yahalom-Mack et al. 2014b).

Outside the eastern Mediterranean and the Levantine corridor, new evidence suggests that copper and bronze production was organized quite differently. Accordingly, explanations for the rise of iron in these regions cannot rely on socioeconomic models that contrast centralized copper metallurgy and "democratic" iron metallurgy. Copper-smelting landscapes in the eastern Black Sea region are characterized by large numbers of highly dispersed smelting sites. Although production occurred on a massive scale in aggregate, the output of any one site was relatively modest, perhaps three orders of magnitude less than the largest Levantine sites. Integration of spatial data with chemical analysis of slags reveals that each of these smelting sites was receiving ore from distinct mines within a zoned ore body, suggesting a lack of coordination in multiple stages of metal production (Erb-Satullo et al. 2017). 
With dates spanning 1300-800 BC (Erb-Satullo et al. 2018), these copper production sites mostly predate the major expansion of iron artifacts on the Black Sea (see Papuashvili 2011). It would be presumptuous, however, to argue that copper production declined in Colchis right at the onset of iron adoption, as bronze was very widely used during the transitional period (Erb-Satullo et al. 2018, pp. 173-175). Nevertheless, we are still a long way from a full picture of the parallel trajectories of these industries.

Intriguingly, there does seem to be some regional variability within the South Caucasus. Metsamor (in the Araxes Valley) was a major metal production site in the late second millennium BC (Crawford 1974, pp. 242-243; McConchie 2004, p. 107; Mkrtchyan et al. 1967; Mkrtiachan 1967). Large amounts of metal production debris were found in the so-called "foundry layer," a 1.2-m-thick stratum characterized by numerous metallurgical hearths/furnaces and large quantities of slags and tuyères (Khanzadyan et al. 1973, pp. 189-190; Maddin 1975). Published analyses and descriptions suggest a connection with copper-base metallurgy (Mkrtchyan et al. 1967), but the technology and chaine opératoire are not fully clear. Iron production remains have been reported in some secondary literature, but conclusive analytical evidence is lacking (Maddin 1975). Given other revisions to previous identifications of iron-smelting debris, it is prudent to approach these identifications with caution. Overall, the spatial centralization and scale of metallurgical activity within a fortress complex suggests a very different mode of production than that seen on the Black Sea coast. Other LBA-EIA hilltop settlements and fortresses also have traces of metal production (Badalyan et al. 2008, p. 65; Erb-Satullo 2018; Gzelishvili 1964, pp. 31-81), but no fortress workshop on the scale of Metsamor has been identified.

It very well may be that there was a degree of centralization in metal production among the fortresses that characterize the Late Bronze and Early Iron Ages of the central South Caucasus (modern-day eastern Georgia and Armenia). Still, the organization of production within these fortified hilltop complexes remains an open question. For instance, how are we to interpret the massive quantities of production debris from Metsamor in comparison with smaller quantities at other hilltop sites, some of which are fairly modest in size? Regardless, metal production in the South Caucasus took place in a very different social and economic context than in the Levant. Explanations for the rise of iron must take into account these regional differences in the organization of metal production.

\section{Methodological and Theoretical Directions for Future Research}

The first 50 years or so of systematic archaeometallurgical research on the rise of iron in the Near East focused predominantly, though not exclusively, on the analysis of finished iron artifacts, with particular attention paid to carburization and techniques of heat treatment. While these efforts have accumulated an impressive dataset, the overall evidence that increased hardness was the driving factor behind the spread of iron is rather equivocal. Many early iron artifacts are steel, but evidence for intentionality and control of carburization is weak. The challenges of sampling well-preserved artifacts make large-scale metallographic research programs difficult 
to undertake. Nevertheless, it is encouraging to see scholars continuing to expand the metallographic dataset with well-dated finds, despite these challenges (EliyahuBehar and Yahalom-Mack 2018).

A significant issue for understanding the social context of metal production is that workshop contexts may be quite ephemeral, and it is often quite difficult to distinguish between different pyrotechnological installations. The increasing focus on Near Eastern production sites and metallurgical debris, which builds on earlier work (see Bachmann 1982; Koucky and Steinberg 1982; Rothenberg 1990), is a promising trend. Careful microstructural and mineralogical analyses are necessary to distinguish between partially reacted iron ores, iron oxides that crystallized from the slag melt, and secondary iron oxides that formed from what was originally particles or aggregates of iron metal. As such, precise descriptions and publication of multiple high-quality microscope images are of paramount importance. Increasing collaboration between archaeometallurgical researchers and the excavators of these sites, either during the process of excavation (Eliyahu-Behar et al. 2012; Veldhuijzen 2009c) or during postexcavation analysis (Erb-Satullo and Walton 2017), has been instrumental in opening up these opportunities. Attempts to study the circulation of iron by matching slag inclusions in iron artifacts to slags at smelting sites (e.g., Blakelock et al. 2009) will benefit from a larger dataset of primary production debris. Following the pioneering model of Rothenberg (1990) and the German Mining Museum (Hauptmann 2007), there are more and more field projects where issues of technological change and the organization of production are directly integrated into the primary research aims (Erb-Satullo 2018; Humphris and Rehren 2014; Levy et al. 2014a; Veldhuijzen and Rehren 2007; Yagel et al. 2016). These kinds of projects are essential, as the study of metal production requires careful attentiveness to classes of artifacts that are often overlooked.

Metallurgically oriented survey projects represent another promising approach for the study of iron adoption. Forested mountainous regions are difficult to survey, but fieldwork has shown that they are often rich in metal production remains (Belli 1991; Erb-Satullo et al. 2017; Lutz et al. 1994; Maisuradze and Gobedzhischvili 2001; Yener 2000, p. 73ff). Dating metallurgical landscapes is a significant challenge, but furnace slags often encase datable charcoal, permitting a direct date of the slag in question. These techniques have been applied to metallurgical landscapes in the Caucasus (Erb-Satullo et al. 2018), and they might be suitable for the smelting landscapes of eastern Anatolia described by Belli (1991). Survey, excavation, and analysis of metal production sites in polymetallic ore-bearing zones will prove essential for substantiating theories about how iron emerged from experimentation with copper deposits. Such experimentation likely took place at smelting sites relatively close to the ore deposits, so proper investigation of these areas is essential.

The recovery, analysis, and dating of production debris - at both settlement sites and primary production areas-provide an opportunity to address questions about the social context of production. The relationships between metalworkers and institutions of political authority are particularly important to the study of iron adoption. As shown above, spatial associations between workshop debris and institutional structures have commonly been used to argue for control over production. Yet, the imposition of control does not always map onto spatial relationships in a direct and 
straightforward manner (Erb-Satullo et al. 2017, pp. 110-111). Production may take place in spatially disparate workshops yet still be centrally managed (Martinón-Torres et al. 2014), and a workshop located next to a temple may be an unwelcome neighbor rather than a temple-administered enterprise. Spatial relationships do affect the ability to project power, but scholars must consider such interpretations carefully and integrate other lines of evidence where possible (see Erb-Satullo et al. 2017).

Comparative examination of copper alloy and iron metallurgy is another key element of ongoing efforts to understand the spread of iron. This applies not just to the numerous examples discussed above where both kinds of production debris occur in the same workshops (e.g., Eliyahu-Behar et al. 2012; Roames 2011). To understand the social and economic forces driving the spread of iron, scholars also must have a sound grasp of parallel trajectories in copper alloy metallurgy. Although there is an impressive and growing body of research on Late Bronze and Early Iron Age copper production in some areas (Ben-Yosef et al. 2012; Erb-Satullo et al. 2017; Knapp 2012; Levy et al. 2014a; Yagel et al. 2016), there are significant lacunae. Little work has explored Late Bronze and Early Iron Age copper mining and smelting sites in Anatolia. Given the rich record of mining and metallurgy in other periods (cf. De Jesus and Dardeniz 2015), such production sites almost certainly exist (see Belli 1991; Lehner 2017; Lutz et al. 1994; Seeher 2010, p. 224), but they have not received the attention they deserve. These gaps hinder our understanding of metal economies in a crucial region during the expansion of iron use.

The search for technological links between copper and iron metallurgy forms an important subset of the broader comparative analysis. What elements of second-millennium copper production practice laid important groundwork for the development of iron smelting? Conversely, what practices or behaviors are preserved in early ironmaking traditions that reflect earlier (or contemporary) copper production practices? Conclusive evidence of iron produced from copper gossans would provide such a link. The examination of technological links has the potential not only to illuminate the mechanism by which iron smelting was invented but also to reveal relationships between copper and iron metalworkers that may have impacted its spread.

Mapping trajectories of adoption, rather than identifying the earliest iron artifacts, is yet another promising development. More recent syntheses have covered less geographical territory than Waldbaum's early efforts $(1978,1999)$, but the detail within those more geographically constrained studies has complemented the earlier work (Gottlieb 2010; McConchie 2004; Yahalom-Mack and Eliyahu-Behar 2015; Yahalom-Mack et al. 2017). Such approaches highlight innovation in iron as an extended process and permit a more richly textured understanding of the forces that affected adoption in different regions.

Work on metal production and use outside the Levant and eastern Mediterranean is crucially important for developing a robust understanding of the varying social conditions that led to the adoption of iron. This is not to discourage research on iron in the eastern Mediterranean, as much remains unclear even in this region. For good reason, the Levant and eastern Mediterranean will continue to play a key role in understanding the advent of iron. At the same time, research on metal assemblages and production sites in Anatolia, the Caucasus, and Iran will answer many questions about how differing social conditions affected innovation and adoption patterns. 
Though recent research in the South Caucasus has revised the region's claim to the earliest iron smelting, this region has the potential to match the Levant as a key place for analyzing patterns of iron adoption, due to its wealth of metallurgical remains. Anatolia's importance in early iron stems from its early textual references to iron (Dercksen 2005), the earliest evidence of iron metallurgical debris (Akanuma 2007), and the number of early iron objects found there (Yalçin 1999). Further archaeological work in the region, particularly surveys in ore-bearing zones, may resolve lingering questions about the origins of extractive iron metallurgy.

The accumulation of fieldwork and laboratory analysis will allow us to address key comparative questions about the nature of iron innovation and adoption. One key question is the effect that a thriving bronze industry had on the emergence of iron. While some regions that adopted iron may have had less access to copper and its alloys, in others, iron was adopted in regions where nonferrous metals were plentiful. Did expertise in bronze metallurgy engender conservatism or stimulate pyrotechnological innovation?

The link between the spread of iron and contemporary political developments is another common theme. What effect did Early Iron Age political fragmentation in the eastern Mediterranean have on the spread of iron? The development of new metal supplies (both copper and iron) does seem to characterize the southern Levant during this period. Comparative study of iron adoption in regions less affected by this collapse allows scholars to test these models. Somewhat later, in the first millennium BC, expansionary states like Assyria and Urartu made and used large quantities of iron. In one sense, the period of political fragmentation that corresponds with early iron adoption in the Levant contrasts with the imperial consolidation that drove the expansion of the iron economy in the ninth to seventh centuries BC in Mesopotamia, eastern Anatolia, and perhaps Egypt. In another sense, though, these models associate iron with the establishment of political authority, by small-scale local elites in the former instance and by large imperial states in the latter. As more and more iron workshops come to light, we will increasingly be able to assess the accuracy and universality of this model. For instance, it is unclear how involved these states were in the administration of production rather than simply the consumption of iron. Analyzing how different social conditions impacted patterns of iron adoption has broader implications for understanding the relationship between technological and social change.

In aggregate, these avenues for future research promise to move the study of iron innovation beyond the discussion of untested models and to provide a coherent picture of a technology that ultimately had a transformative impact across Eurasia. At its heart, the study of iron innovation is, on one hand, an investigation of geological, environmental, and thermodynamic knowledge, and on the other, a study of the social, cultural, and political factors that affected the spread of that knowledge. Iron, therefore, offers excellent perspective on how people navigated the complex interplay between the natural and the social worlds.

Acknowledgments Jason Ur, Karl Lamberg-Karlovsky, Rowan Flad, and David Killick provided helpful comments on an early version of this manuscript. The research was supported by a National Science Foundation Graduate Research Fellowship (DGE0644491 and DGE1144152) and a National Science 
Foundation Doctoral Dissertation Improvement Grant (BCS-1338893). Thanks are due to the participants in the arch-metals listserv for clarifying details about Widmanstätten structures and for pointing me in the direction of some pre-Childe characterizations of iron as a "democratizing" innovation. I also benefitted from discussions about iron metallography with Brian Gilmour and about textual references to iron with Joshua Walton and Gojko Barjamovic. I would like to thank the editors and five reviewers whose detailed comments and suggestions greatly improved the paper.

Open Access This article is distributed under the terms of the Creative Commons Attribution 4.0 International License (http://creativecommons.org/licenses/by/4.0/), which permits unrestricted use, distribution, and reproduction in any medium, provided you give appropriate credit to the original author(s) and the source, provide a link to the Creative Commons license, and indicate if changes were made.

\section{References Cited}

Abramishvili, R. (1957). Samtavris samarovanze aghmochenili gviani brinjaos khanisa da rk'inis parto atvisebis khanis dzeglebis datarighebisatvis. Sakartvelos Sakhelmts'ipo Muzeumis Moambe 19-A and 21-B: $115-140$.

Akanuma, H. (2001). Iron objects from stratum II at Kaman-Kalehöyük: Correlation between composition and archaeological levels. Anatolian Archaeological Studies/Kaman-Kalehöyük 10: 181-190.

Akanuma, H. (2002). Iron objects from the architectural remains of stratum III and stratum II at KamanKalehöyük: Correlation between composition and archaeological levels. Anatolian Archaeological Studies/Kaman-Kalehöyük 11: 191-200.

Akanuma, H. (2003). Further archaeometallurgical study of 2nd and 1st millennium BC iron objects from Kaman-Kalehöyük. Anatolian Archaeological Studies/Kaman-Kalehöyük 12: 137-149.

Akanuma, H. (2006). Changes in iron use during the 2nd and 1st millennia BC at Kaman-Kalehöyük. Anatolian Archaeological Studies/Kaman-Kalehöyük 15: 207-222.

Akanuma, H. (2007). Analysis of iron and copper production activity in central Anatolia during the Assyrian Colony period. Anatolian Archaeological Studies/Kaman-Kalehöyük 16: 125-139.

Akanuma, H. (2008). The significance of Early Bronze Age iron objects from Kaman-Kalehöyük. Anatolian Archaeological Studies/Kaman-Kalehöyük 17: 313-320.

Akhvlediani, N. (2005). Problems of the chronology of Late Bronze Age and Early Iron Age sites in eastern Georgia (Kvemo Sasireti hoard). Ancient Civilizations from Scythia to Siberia 11: 257-295.

Alamri, Y., and Hauptmann, A. (2013). The iron ore mine of Mugharet el-Wardeh/Jordan in southern Bilad al-Sham: Excavation and new dating. In Humphris, J., and Rehren, T. (eds.), World of Iron, Archetype, London, pp. 214-222.

Apakidze, J. (2009). Die Spätbronze- und Früheisenzeit in West- und Zentralkaukasien: Chronologische Studien zur Kolchis-Kultur, Marie Leidorf GMBH, Rahden, Germany.

Apollonius of Rhodes. (1971). The Argonautica, trans. Rieu, E. V., Penguin, London.

Aubet, M. E. (2008). Political and economic implications of the new Phoenician chronologies. In Sagona, C. (ed.), Beyond the Homeland: Markers in Phoenician Chronology, Peeters, Leuven, pp. 247-259.

Bachmann, H.-G. (1982). Copper smelting slags from Cyprus:Rreview and classification of analytical data. In Muhly, J. D., Maddin, R., and Karageorghis, V. (eds.), Acta of the International Archaeological Symposium on Early Metallurgy in Cyprus, 4,000-500 BC, Larnaca, Cyprus 1-6 June 1981, Pierides Foundation, Nicosia, pp. 143-151.

Badaljan, R. S., Edens, C., Gorny, R., Kohl, P. L., Stronach, D., Tonikjan, A. V., Hamayakjan, S., Mandrikjan, S., and Zardarjan, M. (1993). Preliminary report on the 1992 excavations at Horom, Armenia. Iran 31: 1-24.

Badalyan, R. S., Avetisyan, P., and Smith, A. T. (2009). Peridization and chronology of southern Caucasia: From the Early Bronze Age through the Iron III period. In Smith, A. T., Badalyan, R. S., and Avetisyan, P. (eds.), The Archaeology and Geography of Ancient Transcaucasian Societies, Volume 1: The Foundations of Research and Regional Survey in the Tsaghkahovit Plain, Armenia, Oreintal Institute, University of Chicago, Chicago, pp. 33-93.

Badalyan, R. S., Smith, A. T., Khatchadourian, L., and Avetisyan, P. S. (2008). Village, fortress and town in Bronze and Iron Age southern Caucasia: A preliminary repart on the 2003-2006 investigations 
of Project ArAGATS on the Tsaghkahovit Plain, Republic of Armenia. Archäologische Mitteilungen aus Iran und Turan 40: 45-105.

Baldi, J., and Roux, V. (2016). The innovation of the potter's wheel: A comparative perspective between Mesopotamia and the southern Levant. Levant 48: 236-253.

Barceló, J. A., Capuzzo, G., and Bogdanović, I. (2014). Modeling expansive phenomena in early complex societies: The transition from Bronze Iron Age in prehistoric Europe. Journal of Archaeological Method and Theory 21: 486-510.

Bell, C. (2012). The merchants of Ugarit: Oligarchs of the Late Bronze Age trade in metals. In Kassianidou, V., and Papasavvas, G. (eds.), Eastern Mediterranean Metallurgy and Metalwork in the Second Millennium BC, Oxbow Books, Oxford, pp. 180-187.

Belli, O. (1991). Ore deposits and minig in eastern Anatolia in the Urartian period: Silver, copper, and iron. In Merhav, R. (ed.), Urartu: A Metalworking Center in the First Millennium BCE, The Israel Museum, Jerusalem, pp. 15-41.

Ben-Yosef, E. (2010). Technology and Social Process: Oscillations in Iron Age Copper Production and Power in Southern Jordan, Ph.D. dissertation, Department of Anthropology, University of California, San Diego.

Ben-Yosef, E. (2012). A unique casting mold from the new excavations at Timna Site 30: Evidence of western influence? In Kassianidou, V., and Papasavvas, G. (eds.), Eastern Mediterranean Metallurgy and Metalwork in the Second Millennium BC, Oxbow Books, Oxford, pp. 188-196.

Ben-Yosef, E., Levy, T. E., Higham, T., Najjar, M., and Tauxe, L. (2010). The beginning of Iron Age copper production in the southern Levant: New evidence from Khirbat al-Jariya, Faynan, Jordan. Antiquity 84: 724-746.

Ben-Yosef, E., Shaar, R., Tauxe, L., and Ron, H. (2012). A new chronological framework for Iron Age copper production at Timna (Israel). Bulletin of the American Schools of Oriental Research 367: 31-71.

Blakelock, E., Martinón-Torres, M., Veldhuizjen, H. A., and Young, T. (2009). Slag inclusions in iron objects and the quest for provenance: An experiment and a case study. Journal of Archaeological Science 36: 1745-1757.

Boroffka, N., Cierny, J., Lutz, J., Parzinger, H., Pernicka, E., and Weisgerber, G. (2002). Bronze Age tin from Central Asia: Preliminary notes. In Boyle, K., Renfrew, C., and Levine, M. (eds.), Ancient Interactions: East and West in Eurasia, McDonald Institute of Archaeological Research, Cambridge.

Branting, S., Lehner, J. W., Baltalı-Tırpan, S., Graff, S. R., Marston, J. M., Kalaycı, T., Özarslan, Y., Langis-Barsetti, D., Proctor, L., and Paulsen, P. (2017). The Kerkenes project 2015-2016. In Steadman, S. R., and McMahon, G. (eds.), The Archaeology of Anatolia, Volume II: Recent Discoveries (2015-2016), Cambridge Scholars Publishing, Cambridge, pp. 154-175.

Brinkman, J. A. (1987). Textual evidence for anomalous quantities of iron at Alalakh and Nuzi in the Middle and Late Bronze Ages. Nouvelles Assyriologiques Brèves et Utilitaires 34-35.

Britvin, S. N., Murashko, M. N., Vapnik, Y., Polekhovsky, Y. S., and Krivovichev, S. V. (2015). Earth's phosphides in Levant and insights into the source of Archean prebiotic phosphorus. Scientific Reports 5: 8355 .

Buchwald, V. F. (1992). On the use of iron by the Eskimos in Greenland. Materials Characterization 29: 139-176.

Burmeister, S., and Bernbeck, R. (eds.) (2017). The Interplay of People and Technologies: Archaeological Case Studies on Innovations, Edition Topoi, Berlin.

Burney, C. (1996). "The highland sheep are sweeter..." Bunnens, G. (ed.), Cultural Interaction in the Ancient Near East: Papers Read at a Symposium Held at the University of Melbourne, Department of Classics and Archaeology (29-30 September 1994), Peeters, Louvain, pp. 1-15.

Burney, C. (2004). Historical Dictionary of the Hittites, Scarecrow Press, Lanham, MD.

Çevik, Ö. (2008). Periodisation criteria for Iron Age chronology in eastern Anatolia and neighboring regions. Ancient Near Eastern Studies 45: 1-20.

Cevizoğlu, H., and Yalçin, Ü. (2012). A blacksmith's workshop at Klazomenai. In Çilingiroğlu, A., and Sagona, A. (eds.), Anatolian Iron Ages 7: Proceedings of the Seventh Anatolian Iron Ages Colloquium held at Edirne, 19-24 April 2010, British Institute at Ankara, London, pp. 73-97.

Charalambous, A. (2016). A diachronic study of Cypriot copper alloy artefacts. Journal of Archaeological Science: Reports 7: 566-573. 
Charalambous, A., Kassianidou, V., and Papasavvas, G. (2014). A compositional study of Cypriot bronzes dating to the Early Iron Age using portable X-ray fluorescence spectrometry (pXRF). Journal of Archaeological Science 46: 205-216.

Charlton, M. F., Crew, P., Rehren, T., and Shennan, S. J. (2010). Explaining the evolution of ironmaking recipes - An example from northwest Wales. Journal of Anthropological Archaeology 29: $352-367$.

Chelidze, Z. A. (1977). Rezul'taty arkheomagnitnogo issledovaniya nekotorykh arkheologicheskikh ob'yektov (Results of archaeomagnetic research of several archaeological features). Voprosy Drevney Istorii: Kavkazsko-Blizhnevoctochny Sbornik 5: 142-145.

Childe, V. G. (1944). Archaeological ages as technological stages. Journal of the Royal Anthropological Institute 74: 7-24.

Childe, V. G. (1951). Man Makes Himself, New American Library, New York.

Çifçi, A. (2017). The Socio-Economic Organisation of the Urartian Kingdom, Brill, Leiden.

Comelli, D., D’Orazio, M., Folco, L., El-Halwagy, M., Frizzi, T., Alberti, R., Capogrosso, V., Elnaggar, A., Hassan, H., Nevin, A., Porcelli, F., Rashed, M. G., and Valentini, G. (2016). The meteoritic origin of Tutankhamun's iron dagger blade. Meteoritics \& Planetary Science 51: 1301-1309.

Constantinou, G. (2012). Late Bronze Age copper production in Cyprus from a mining geologists's perspective. In Kassianidou, V., and Papasavvas, G. (eds.), Eastern Mediterranean Metallurgy and Metalwork in the Second Millennium BC, Oxbow Books, Oxford, pp. 4-13.

Cooke, S. R. B., and Ashenbrenner, S. (1975). The occurence of metallic iron in ancient copper. Journal of Field Archaeology 2: 251-266.

Cordani, V. (2016). The development of the Hittite iron industry: A reappraisal of the written sources. Die Welt des Orients 46: 162-176.

Courtois. (1982). L'activité métallurgique et les bronzes d'Enkomi au Bronze Récent (1650-1100 avant J.-C.). In Muhly, J. D., Maddin, R., and Karageorghis, V. (eds.), Acta of the International Archaeological Symposium on Early Metallurgy in Cyprus, 4,000-500 BC, Larnaca, Cyprus 1-6 June 1981, Pierides Foundation, Nicosia, pp. 155-174.

Craddock, P. T., and Meeks, N. D. (1987). Iron in ancient copper. Archaeometry 29: 187-204.

Crawford, H. E. W. (1974). The problem of tin in Mesopotamian bronzes. World Archaeology 6: 242-247.

Curtis, J. (2013). An Examination of Late Assyrian Metalwork with Special Reference to Nimrud, Oxbow, Oxford.

Curtis, J. E., Wheeler, T. S., Muhly, J. D., and Maddin, R. (1979). Neo-Assyrian ironworking technology. Proceedings of the American Philosophical Society 123: 369-390.

Danti, M. (2013). Late Bronze and Early Iron Age in northwestern Iran. In Potts, D. T. (ed.), Oxford Handbook of Ancient Iran, Oxford University Press, Oxford.

Danti, M. D., and Cifarelli, M. (2015). Iron II warrior burials at Hasanlu Tepe, Iran. Iranica Antiqua 50: 61-157.

Davis, D., Maddin, R., Muhly, J. D., and Stech, T. (1985). A steel pick from Mt. Adir in Palestine. Journal of Near Eastern Studies 44: 41-51.

De Jesus, P. S., and Dardeniz, G. (2015). Archaeological and geological concepts on the topic of ancient mining. Bulletin of the Mineral Research and Exploration Institute of Turkey 151: 231-246.

Dercksen, J. G. (2005). Metals according to documents from Külepe-Kanish dating to the Old Assyrian Colony period. In Yalçin, Ü. (ed.), Anatolian Metal III, Deutsches Bergbau Museum, Bochum, pp. 17-34.

Doonan, R. C. P., Cadogan, G., and Sewell, D. (2012). Standing on ceremony: The metallurgical finds from Maroni-Vournes, Cyprus. In Kassianidou, V., and Papasavvas, G. (eds.), Eastern Mediterranean Metallurgy and Metalwork in the Second Millennium BC, Oxbow Books, Oxford, pp. 48-57.

Eliyahu-Behar, A., Shilstein, S., Raban-Gerstel, N., Goren, Y., Gilboa, A., Sharon, I., and Weiner, S. (2008). An integrated approach to reconstructing primary activities from pit deposits: Iron smithing and other activities at Tel Dor under Neo-Assyrian domination. Journal of Archaeological Science 35: 2895-2908.

Eliyahu-Behar, A., and Yahalom-Mack, N. (2018). Reevaluating early iron-working skills in the southern Levant through microstructure analysis. Journal of Archaeological Science: Reports 18: 447-462.

Eliyahu-Behar, A., Yahalom-Mack, N., Gadot, Y., and Finkelstein, I. (2013). Iron smelting and smithing in major urban centers in Israel during the Iron Age. Journal of Archaeological Science 40: 4319-4330. 
Eliyahu-Behar, A., Yahalom-Mack, N., Shilstein, S., Zukerman, A., Shafer-Elliot, Maeir, A. M., Boaretto, E., Finkelstein, I., and Weiner, S. (2012). Iron and bronze production in Iron Age IIA Philistia: New evidence from Tell es-Safi/Gath, Israel. Journal of Archaeological Science 39: 255-267.

Engels, F. (1902). The Origin of the Family, Private Property, and the State, Charles H. Kerr, Chicago.

Erb-Satullo, N. L., Gilmour, B. J. J., and Khakhutaishvili, N. (2014). Late Bronze Age and Early Iron Age copper smelting technologies in the South Caucasus: The view from ancient Colchis c. 1500-600 BC. Journal of Archaeological Science 49: 147-159.

Erb-Satullo, N. L., Gilmour, B. J. J., and Khakhutaishvili, N. (2017). Copper production landscapes of the South Caucasus. Journal of Anthropological Archaeology 47: 109-126.

Erb-Satullo, N. L. (2018). Patterns of settlement and metallurgy in Late Bronze-Early Iron Age Kvemo Kartli, southern Georgia. In Anderson, W., Hopper, K., and Robinson, A. (eds.), Finding Common Ground in Diverse Environments: Landscape Archaeology in the South Caucasus, OREA, Austrian Academy of Sciences, Vienna, pp. 37-52.

Erb-Satullo, N. L., Gilmour, B. J. J., and Khakhutaishvili, N. (2015). Crucible technologies in the Late Bronze-Early Iron Age South Caucasus: Copper processing, tin bronze production, and the possibility of local tin ores. Journal of Archaeological Science 61: 260-276.

Erb-Satullo, N. L., Gilmour, B. J. J., and Khakhutaishvili, N. (2018). The ebb and flow of copper and iron smelting in the South Caucasus. Radiocarbon 60: 159-180.

Erb-Satullo, N. L., and Walton, J. T. (2017). Iron and copper production at Iron Age Ashkelon: Implications for the organization of Levantine metal production. Journal of Archaeological Science: Reports 15: 8-19.

Feldman, M. H. (2006). Diplomacy by Design: Luxury Arts and an "International Style" in the Ancient Near East, 1400-1200 BCE, University of Chicago Press, Chicago.

Gale, N. H. (1999). Lead isotope characterization of the ore deposits of Cyprus and Sardinia and its application to the discovery of the sources of copper for Late Bronze Age oxhide ingots. In Young, S. M. M., Pollard, A. M., Budd, P., and Ixer, R. A. (eds.), Metals in Antiquity, Archaeopress, Oxford.

Gale, N. H., Bachmann, H. G., Rothenberg, B., Stos-Gale, Z. A., and Tylecote, R. F. (1990). The adventitious production of iron in the smelting of copper. In Rothenberg, B. (ed.), The Ancient Metallurgy of Copper, Institute for Archaeo-Metallurgical Studies, Institute of Archaeology, University College, London, pp. 182-191.

Gale, N. H., and Stos-Gale, Z. A. (1982). Bronze Age copper sources in the Mediterranean: A new approach. Science 216: 11-19.

Gale, N. H., and Stos-Gale, Z. A. (2012). The role of the Apliki mine region in the post c. 1400 BC copper production and trade networks in Cyprus. In Kassianidou, V., and Papasavvas, G. (eds.), Eastern Mediterranean Metallurgy and Metalwork in the Second Millennium BC, Oxbow Books, Oxford, pp. 70-82.

Garner, J. (2015). Bronze age tin mines in central Asia. In Hauptmann, A., and Modaressi-Tehrani, D. (eds.), Archaeometallugy in Europe III, Deutsches Bergbau-Museum, Bochum, pp. 135-143.

Genz, H. (2003). The Early Iron Age in central Anatolia. In Fischer, B., Genz, H., Jean, É., and Köruoğlu, K. (eds.), Identifying Changes: The Transition from Bronze to Iron Ages in Anatolia and Its Neighboring Regions: Proceedings of the International Workshop, Istanbul, November 8-9, 2002, Türk Eskiçă̆ Bilimleri Enstitüsü, Istanbul, pp. 179-191.

Gordon, R. B. (1997). Process deduced from ironmaking wastes and artefacts. Journal of Archaeological Science 24: 9-18.

Goren, Y., Bunimovitz, S., Finkelstein, I., and Na'Aman, N. (2003). The location of Alashiya: New evidence from petrographic investigation of Alashiyan tablets from El-Amarna and Ugarit. American Journal of Archaeology 107: 233-255.

Gottlieb, Y. (2010). The advent of the age of iron in the land of Israel: A review and reassessment. Tel Aviv 37: 89-110.

Gzelishvili, I. A. (1964). Zhelezoplavil'noe Proizvodstvo v Drevney Gruzii (Iron Smelting Production in Ancient Georgia), Metsniereba, Tbilisi.

Harrison, T. P. (2009). Neo-Hittites in the "Land of Palistin": Renewed investigation at Tell Ta'yinat on the plain of Antioch. Near Eastern Archaeology 72: 174-179.

Hauptmann, A. (2007). The Archaeometallurgy of Copper: Evidence from Faynan, Jordan, Springer, Berlin.

Hooker, J. T. (1982). The end of Pylos and the Linear B evidence. Studi Micenei ed Egeo-Anatolici 23: 209-217. 
Horne, L. (1982). Fuel for the metal worker: The role of charcoal and charcoal production in ancient metallurgy. Expedition 25(1): 6-13.

Hüls, M., Grootes, P. M., and Nadeau, M.-J. (2011). Sampling iron for radiocarbon dating: Influence of modern steel tools on ${ }^{14} \mathrm{C}$ dating of ancient iron artifacts. Radiocarbon 53: $151-160$.

Humphris, J., and Rehren, T. (2014). Iron production and the Kingdom of Kush: An introduction to UCL Qatar's research in Sudan. In Lohwasser, A., and Wolf, P. (eds.), Ein Forscherleben zwischen den Welten: Zum 80: Geburtstag von Steffen Wenig, Mitteilungen der Sudanarchäologischen Gesellschaft zu Berlin, Berlin, pp. 177-190.

Hunt, C. O., Gilbertson, D. D., and El-Rishi, H. A. (2007). An 8000-year history of landscape, climate and copper exploitation in the Middle East: The Wadi Faynan and the Wadi Dana National Reserve in southern Jordan. Journal of Archaeological Science 34: 1306-1338.

Inanishvili, G. (2007). About the history of iron production in Georgia. Metalla 14: 1-62.

Jambon, A. (2017). Bronze Age iron: Meteoritic or not? A chemical strategy. Journal of Archaeological Science 88: 47-53.

Japaridze, O. (1999). From the Middle Bronze to the Early Iron Age in Georgia. In Soltes, O. Z. (ed.), National Treasures of Georgia, Philip Wilson., London, pp. 62-65.

Johnson, D., Tylsesley, J., Lowe, T., Withers, P. J., and Grady, M. M. (2013). Analysis of a prehistoric Egyptian iron bead with implications for the use and perception of meteorite iron in ancient Egypt. Meteoritics and Planetary Science 48: 997-1006.

Karageorghis, V. (1982). Metallurgy in Cyprus during the 11th century BC. In Muhly, J. D., Maddin, R., and Karageorghis, V. (eds.), Acta of the International Archaeological Symposium on Early Metallurgy in Cyprus, 4,000-500 BC, Larnaca, Cyprus 1-6 June 1981, Pierides Foundation, Nicosia, pp. 297-301.

Karageorghis, V. (1983). Paleopaphos-Skales: An Iron Age Cemetery in Cyprus, Universitätsverlag Konstanz GmbH, Konstanz.

Karageorghis, V., and Kassianidou, V. (1999). Metalworking and recycling in Late Bronze Age CyprusThe evidence from Kition. Oxford Journal of Archaeology 18: 171-188.

Karageorghis, V., and Raptou, E. (2016). Paleopaphos-Skales: Tombs of the Late Cypriot IIB and CyproGeometric Periods (Excavations of 2008 and 2011), The Cyprus Institute, Nicosia.

Kassianidou, V. (1999). Bronze Age copper smelting technology in Cyprus-The evidence from Politico Phorades. In Young, S. M. M., Pollard, A. M., Budd, P., and Ixer, R. A. (eds.), Metals in Antiquity, Archaeopress, Oxford.

Kassianidou, V. (2012). Metallurgy and metalwork in Enkomi: The early phases. In Kassianidou, V., and Papasavvas, G. (eds.), Eastern Mediterranean Metallurgy and Metalwork in the Second Millennium BC, Oxbow Books, Oxford, pp. 94-106.

Kassianidou, V. (2014). Cypriot copper for the Iron Age world of the eastern Mediterranean. In Webb, J. M. (ed.), Structure, Measurement and Meaning: Studies on Prehistoric Cyprus in Honour of David Frankel, Åströms, Uppsala, pp. 261-271.

Kaufman, B., Docter, R., Fischer, C., Chelbi, F., and Maraoui Telmini, B. (2016). Ferrous metallurgy from the Bir Massouda metallurgical precinct at Phoenician and Punic Carthage and the beginning of the North African Iron Age. Journal of Archaeological Science 71: 33-50.

Khakhutaishvili, D. A. (1977). K khronologii kolkhidsko-khalibskogo tsentra drevnezheleznoy metallurgii (On the chronology of the Colcho-Khalibian center of early iron metallurgy). Voprosy Drevney Istorii (Kavkazsko-Blizhnevostochny Sbornik) 5: 119-141.

Khakhutaishvili, D. A. (1981). Yugo-zapadnaya Gruzia v VIII-VI vv. do n. e. (Southwestern Georgia in the 8th-6th centuries BC). In Lordkipanidze, O. D. (ed.), Demograficheskaya Situatsiya $v$ Prichyophomor'ye (Kolkhida) v Period Velikoy Grecheskoy Kolonizatsii (The Demographic Situation on the Black Sea Coast in the Period of the Great Greek Colonization), Metsniereba, Tbilisi, pp. 329-333.

Khakhutaishvili, D. A. (2009). The Manufacture of Iron in Ancient Colchis, Archaeopress, Oxford.

Khanzadyan, E. V., Mkrtchyan, K. A., and Parsamyan, E. S. (1973). Metsamor (in Armenian with Russian and English Summaries), Akademii Nauk Armyanskoy SSR, Erevan.

Killick, D. (2009). Cairo to Cape: The spread of metallurgy through eastern and southern Africa. Journal of World Prehistory 22: 399-414.

Killick, D. (2015). Invention and innovation in African iron-smelting technologies. Cambridge Archaeological Journal 25: 307-319. 
Kim, J. (2001). Elite strategies and the spread of technological innovation: The spread of iron in the Bronze Age societies of Denmark and southern Korea. Journal of Anthropological Archaeology 20: $442-478$.

Knapp, A. B. (1993). Thalassocracies in Bronze Age eastern Mediterranean trade: Making and breaking a myth. World Archaeology 24: 332-347.

Knapp, A. B. (2012). Metallurgical production and trade on Bronze Age Cyprus: Views and variations. In Kassianidou, V., and Papasavvas, G. (eds.), Eastern Mediterranean Metallurgy and Metalwork in the Second Millennium BC, Oxbow Books, Oxford, pp. 14-25.

Knapp, A. B. (2013). The Archaeology of Cyprus from Earliest Prehistory through the Bronze Age, Cambridge University Press, Cambridge.

Knapp, A. B., and Kassianidou, V. (2008). The archaeology of Late Bronze Age copper production: Politiko Phorades on Cyprus. In Yalçin, Ü. (ed.), Anatolian Metal IV, Bochum Vereinigung der Freunde von Kunst und Kultur im Bergbau, Bochum, Germany, pp. 135-147.

Knapp, A. B., Kassianidou, V., and Donnelly, M. (2001). Copper smelting in Late Bronze Age Cyprus: The excavation at Politiko Phorades. Near Eastern Archaeology 64: 204-210.

Köruoğlu, K. (2003). The transition from Bronze Age to Iron Age in eastern Anatolia. In Fischer, B., Genz, H., Jean, É., and Köruoğlu, K. (eds.), Identifying Changes: The Transition from Bronze to Iron Ages in Anatolia and Its Neighboring Regions: Proceedings of the International Workshop, Istanbul, November 8-9, 2002, Türk Eskiçağ Bilimleri Enstitüsü, Istanbul, pp. 231-244.

Köruoğlu, K., and Konyar, E. (2008). Comments on the Early/Middle Iron Age chronology of the Lake Van Basin. Ancient Near Eastern Studies 45: 123-146.

Košak, S. (1986). The gospel of iron. In Hoffner Jr., H. A., and Beckman, G. M. (eds.), Kaniššuwar: A Tribute to Hans G. Güterbock on His Seventy-Fifth Birthday, May 27, 1983, Oriental Institute, University of Chicago, Chicago, pp. 125-135.

Koucky, F. L., and Steinberg, A. (1982). The ancient slags of Cyprus. In Muhly, J. D., Maddin, R., and Karageorghis, V. (eds.), Acta of the International Archaeological Symposium on Early Metallurgy in Cyprus, 4,000-500 BC, Larnaca, Cyprus 1-6 June 1981, Pierides Foundation, Nicosia, pp. 117-137.

Krauskopf, K. B. (1979). Introduction to Geochemistry, McGraw-Hill, New York.

Lagarce, J. (1983). Herstellung von Kupferrohbarren in Ras ibn Hani (Syrien). Acta Praehistorica et Archaeologica 18: 85-90.

Lam, W. (2014). Everything old is new again? Rethinking the transition to cast iron production in the Central Plains of China. Journal of Anthropological Research 70: 511-542.

Larsen, M. T. (2015). Ancient Kanesh: A Merchant Colony in Bronze Age Anatolia, Cambridge University Press, New York.

Lehner, J. W. (2017). Innovation and continuity of metal production and consumption during the Early Iron Age at Boğazköy-Hattuša. In Schachner, A. (ed.), Innovation versus Beharrung: Was macht den Unterschied des hethitischen Reichs im Anatolien des 2. Jahrtausends v. Chr.? Deutschen Archäologischen Instituts Istanbul, Istanbul.

Levy, T. E., Adams, R. B., Najjar, M., Hauptmann, A., Anderson, J. D., Brandl, B., Robinson, M. A., and Higham, T. (2004). Reassessing the chronology of Biblical Edom: New excavations and C-14 dates from Khirbat en-Nahas (Jordan). Antiquity 78: 865-879.

Levy, T. E., Ben-Yosef, E., and Najjar, M. (2012). New perspectives on Iron Age copper production and society in the Faynan region, Jordan. In Kassianidou, V., and Papasavvas, G. (eds.), Eastern Mediterranean Metallurgy and Metalwork in the Second Millennium BC, Oxbow Books, Oxford, pp. 197-214.

Levy, T. E., Najjar, M., and Ben-Yosef, E. (eds.) (2014a). New Insights into the Iron Age Archaeology of Edom, Southern Jordan: Surveys, Excavations and Research from the Edom Lowlands Regional Archaeology Project (ELRAP), Vol. 1, Cotsen Institute of Archaeology Press, Los Angeles.

Levy, T. E., Najjar, M., Higham, T., Arbel, Y., Muniz, A., Ben-Yosef, E., Smith, N. G., Beherec, M., Gidding, A., Jones, I. W., Frese, D., Smitheram, C., and Robinson, M. (2014b). Excavations at Khirbet en-Nahas, 2002-2009. In Levy, T. E., Najjar, M., and Ben-Yosef, E. (eds.), New Insights into the Iron Age Archaeology of Edom, Southern Jordan: Surveys, Excavations and Research from the Edom Lowlands Regional Archaeology Project (ELRAP), Vol. 1, Cotsen Institute of Archaeology Press, Los Angeles, pp. 89-244.

Liebowitz, H. (1981). Excavations at Tel Yin`am: The 1976 and 1977 seasons: Preliminary report. Bulletin of the American Schools of Oriental Research 243: 79-94. 
Liverani, M. (1987). The collapse of the Near Eastern regional system at the end of the Bronze Age: The case of Syria. In Rowlands, M., Larsen, M. T., and Kristiansen, K. (eds.), Centre and Periphery in the Ancient World, Cambridge University Press, Cambridge, pp. 66-73.

Liverani, M. (2003). The influence of political institutions on trade in the ancient Near East (Late Bronze to Early Iron Age). In Zaccagnini, C. (ed.), Mercanti e politica nel mondo antico, «L'Erma» di Bretschneider, Rome, pp. 119-137.

Liverani, M. (2008). The Late Bronze Age: Materials and mechanisms of trade and cultural exchange. In Aruz, J., Benzel, K., and Evans, J. M. (eds.), Beyond Babylon: Art, Trade, and Diplomacy in the Second Millennium BC, Yale University Press, New Haven, CT, pp. 161-168.

Lordkipanidze, O. (1979). Drevnyaya Kolkhida: Mif i Arkheologiya (Ancient Colchis: Myth and Archaeology), Sabchota Sakartvelo, Tbilisi.

Lordkipanidze, O. (2001). "Gandzebi” kolkhur brinjaos kulturashi (punktiis depinitsiis da kulturul-sotsiologiuri interpretatsiis tsda) ("Hoards" of the Colchian Bronze Culture [an attempt at functional definition and sociological and ethnocultural interpretation]). In, Caucasus Essays on the Archaeology of trhe Neolithic-Bronze Age: Dedicated to the 80th Birthday of Prof. Otar Japaridze, Center for Archaeological Studies of the Georgian Academy of Sciences, Tbilisi, pp. 178-194.

Luciani, M. (2016). Iron smelting and smithing in northern Syria: The context and its interpretation. In Thuesen, I. (ed.), Proceedings of the 2nd International Congress on the Archaeology of the Ancient Near East, University of Bologna/Eisenbraums, Bologna, pp. 823-838.

Luciani, M., Zaghis, F., Salviulo, G., Calliari, I., and Ramous, E. (2003). Iron Age metallurgy: A preliminary study of slags from Tell Shiukh Fawqani (northern Syria). In Archaeometallurgy in Europe: 24-25-26 September 2003: Milan, Italy, Proceedings Vol. 2, Assiciazione Italiana di Metallurgia, Milan, pp. 499-506.

Lutz, J., Pernicka, E., and Wagner, G. A. (1994). Chalkolithische Kupferverhüttung in Murgul, Ostanatolien. In Wartke, R.-B. (ed.), Handwerk und Technologie im Alten Orient, Philipp von Zabern, Mainz, pp. 56-66.

Maddin, R. (1975). Early iron metallurgy in the Near East. Transactions of the Iron and Steel Institute of Japan 15: 59-68.

Maddin, R. (1982). Early iron technology in Cyprus. In Muhly, J. D., Maddin, R., and Karageorghis, V. (eds.), Acta of the International Archaeological Symposium on Early Metallurgy in Cyprus, 4,000500 BC, Larnaca, Cyprus 1-6 June 1981, Pierides Foundation, Nicosia, pp. 303-314.

Maddin, R., Muhly, J. D., and Wheeler, T. S. (1977). How the Iron Age began. Scientific American 237: $122-131$.

Magee, P. (2008). Deconstructing the destruction of Hasanlu: Archaeology, imperialism and the chronology of the Iranian Iron Age. Iraniqua Antiqua 43: 89-106.

Maisuradze, B., and Gobedzhischvili, G. (2001). Alter Bergbau in Ratscha. In Gambashidze, I., Hauptmann, A., Slotta, R., and Yalçin, Ü. (eds.), Georgien: Schätze aus dem Land des goldenen Vlies, Deutsches Bergbau-Museum, Bochum, pp. 130-135.

Maran, J., and Stockhammer, P. (eds.) (2017). Appropriating Innovations: Entangled Knowledge in Eurasia, 5000-1500 BCE, Oxbow Books, Oxford.

Martinón-Torres, M., Li, X. J., Bevan, A., Xia, Y., Zhao, K., and Rehren, T. (2014). Forty thousand arms for a single emperor: From chemical data to the labor organization behind the bronze arrows of the terracotta army. Journal of Archaeological Method and Theory 21: 534-562.

Martirosyan, A. A. (1974). Argishtikhinili, Akademii Nauk Armyanskoy SSR, Erevan.

Masubuchi, M. (2008). Metallographic study on iron and steel arrowheads from Kaman-Kalehöyük. Anatolian Archaeological Studies/Kaman-Kalehöyük 17: 183-194.

Masubuchi, M. (2016). Diachronic Changes in Iron and Steel Production and Cultural Transitions in Central Anatolia, 1650-550 BC, in Light of a New Archaeometallurgical Investigation of Iron and Steel Objects at Kaman-Kalehöyük, Ph.D. dissertation, Institute of Archaeology, University College, London.

Maxwell-Hyslop, K. R., and Hodges, H. W. M. (1966). Three iron swords from Luristan. Iraq 28: $164-176$.

Maxwell-Hyslop, R. (1972). The metals amūtu and aši'u in the Kültepe texts. Anatolian Studies 22: 159-172.

McClellan, J. A. (1975). Iron Objects from Gordion: A Typological and Functional Analysis, Ph.D. dissertation, Department of Classical Archaeology, University of Pennsylvania, Philadelphia.

McConchie, M. (2004). Archaeology at the North-East Anatolian Frontier, V: Iron Technology and Iron Making Communities of the First Millennium BC, Peeters, Louvain, Belgium. 
McNutt, P. (1990). The Forging of Israel: Iron Technology, Symbolism and Tradition in Ancient Society, Almond Press, Decatur, GA.

Melikishvili, G. A. (1962). Kulkha (Iz drevney istorii Yuzhnogo Zakavkaz'ya) (Kulkha [From the ancient history of Southern Transcaucasia]). In Pigulevskaya, H. V., Kallistov, D. P., Katsnelson, I. C., and Korostovtsev, M. A. (eds.), Drevniy mir: Sbornik statey, Izdatel'stvo Vostochnoy Literatury, Moskva, pp. 319-326.

Merhav, R. (ed.) (1991). Urartu: A Metalworking Center in the First Millennium BCE, The Israel Museum, Jerusalem.

Merkel, J. F., and Barrett, K. (2000). 'The adventitious production of iron in the smelting of copper' revisited: Metallographic evidence against a tempting model. Historical Metallurgy 34: 59-66.

Meyer, M. (2017). Iron and consequences of the introduction of its technologies in northern Central Europe. In Burmeister, S., and Bernbeck, R. (eds.), The Interplay of People and Technologies: Archaeological Case Studies on Innovations, Edition Topoi, Berlin, pp. 141-159.

Mikeladze, T. K. (1985). Kolkhetis Adrerkinis Khanis Samarovnebi (Urekisa da Nigvzianis Samarovnebi) (Early Iron Age Colchian Cemeteries [Ureki and Nigvziani Cemeteries]) (in Georgian with Russian summary), Metsniereba, Tbilisi.

Mikeladze, T. K. (1990). K arkheologii Kolkhidy (On the Archaeology of Colchis), Metsniereba, Tbilisi.

Mikeladze, T. K., and Baramidze, M. V. (1977). Kolkhskiy mogil'nik VII-VI vv. do n. e. v c. Nigvziani (Colchian cemetery of the VII-VI c. BC in the village Nigvziani). Korotkiye Schyoty Instituta Arkheologii (Short Accounts of the Institute of Archaeology) 151: 33-39.

Mirau, N. A. (1997). Social context of early ironworking in the Levant. In Aufrecht, W. A., Mirau, N. A., and Gauley, S. W. (eds.), Urbanism in Antiquity: From Mesopotamia to Crete, Sheffield Academic Press, Sheffield, UK, pp. 99-115.

Mkrtchyan, K. A., Barsegyan, L. A., Oganesyan, J. A., Arutyunyan, A. R., and Ayvazian, S. M. (1967). Drevneysheye gorno-metallurgicheskoye cooruzheniye Metsamora (Earliest mining-metallurgical structure at Metsamor). Izvestiya Akademii Nauk Armyanskoy SSR, Nauki o Zemle 17: 69-74.

Mkrtiachan, B. (1967). The mystery of Metsamor. New Orient 6: 76-78.

Moorey, P. R. S. (1991). The decorated ironwork of the Early Iron Age attributed to Luristan in western Iran. Iran 29: 1-12.

Moorey, P. R. S. (1999). Ancient Mesopotamian Materials and Industries: The Archaeological Evidence, Eisenbrauns, Winona Lake, IN.

Morris, I. (1989). Circulation, deposition and the formation of the Greek Iron Age. Man 24: 502-519.

Muhly, J. D. (1980). The Bronze Age setting. In Wertime, T. A., and Muhly, J. D. (eds.), The Coming of the Age of Iron, Yale University Press, New Haven, CT, pp. 25-67.

Muhly, J. D. (1992a). The crisis years in the Mediterranean world: Transition or cultural disintegration. In Ward, W. A., and Sharp Joukowsky, M. (eds.), The Crisis Years: The 12th century BC: From Beyond the Danube to the Tigris, Kendall/Hunt Publishing, Dubuque, IA, pp. 10-26.

Muhly, J. D. (1992b). Review of The Forging of Israel: Iron Technology, Symbolism, and Tradition in Ancient Society by Paula M. McNutt. Journal of the American Oriental Society 112: 696-702.

Muhly, J. D. (2003). Metalworking/mining in the Levant. In Richard, S. (ed.), Near Eastern Archaeology: A Reader, Eisenbrauns, Winona Lake, IN, pp. 174-183.

Muhly, J. D., Maddin, R., Stech, T., and Özgen, E. (1985). Iron in Anatolia and the nature of the Hittite iron industry. Anatolian Studies 35: 67-84.

Muscarella, O. W. (1989). Multi-piece iron swords from Luristan. In de Meyer, L,. and Haerinck, E. (eds.), Archaeologia Iranica et Orientalis: Miscellanea in honorem Louis Vanden Berghe, Peeters, Gent, pp. 349-366.

Muscarella, O. W. (2006). Urartian metal artifacts: An archaeological review. Ancient Civilizations 12: 147-177.

Nakai, I., Abe, Y., Tankrakarn, K., Omura, S., and Erkut, S. (2008). Preliminary report on the analysis of an Early Bronze Age iron dagger excavated from Alacahöyük. Anatolian Archaeological Studies/ Kaman-Kalehöyük 17: 321-323.

Nezafati, N., Pernicka, E., and Momenzadeh, M. (2009). Introduction of the Deh Hosein ancient tincopper mine, western Iran: Evidence from geology, archaeology, geochemistry and lead isotope data. Tüba-ar 12: 223-236.

Nieling, J. (2009). Die Einführung der Eisentechnologie in Südkaukasien und Ostanatolien wahrend der Spätbronze- und Früheisenzeit, Aarhus University Press, Aarhus.

Notis, M. R., Pigott, V. C., McGovern, P. E., Liu, K. H., and Swann, C. P. (1986). The archaeometallurgy of the Iron IA steel. In McGovern, P. E. (ed.), The Late Bronze and Early Iron Ages of Central 
Transjordan: The Baqah Valley Project, 1977-1981, University of Pennsylvania Museum, Philadelphia, PA, pp. 272-278.

Ogden, J. (2000). Metals. In Nicholson, P. T., and Shaw, I. (eds.), Ancient Egyptian Materials and Technology, Cambridge University Press, Cambridge, pp. 148-176.

Özgüç, N. (1976). An ivory box and a stone mould from Acemhöyük. Türk Tarih Kurumu Belleten 40: $547-560$.

Papasavvas, G. (2012). Profusion of Cypriot copper abroad, dearth of bronzes at home: A paradox in Late Bronze Age Cyprus. In Kassianidou, V., and Papasavvas, G. (eds.), Eastern Mediterranean Metallurgy and Metalwork in the Second Millennium BC, Oxbow Books, Oxford, pp. 117-128.

Papuashvili, R. (2011). K voprosu ob absolyutnoy khronologii mogil'nikov kolkhidy epokhi pozdney bronzy-rannego zheleza (On the question of the absolute chronology of the cemeteries of Colchis in the Late Bronze-Early Iron Age). In Albegova, Z. K., Bagaev, M. K., and Korenevskiy, S. N. (eds.), Voprosy Drevney i Srednevekovoy Arkheologii Kavkaza (Questions of Ancient and Medieval Archaeology of the Caucasus), Uchrezhdeniye Rossiyskoy Akademii Nauk Institut Arkheologii, Grozny, Russia, pp. 82-94.

Papuashvili, R. (2012). The Late Bronze/Early Iron Age burial grounds from Tsaishi. In Mehnert, A., Mehnert, G., and Reinhold, S. (eds.), Austausch und Kulturkontakt im Südkaukasus und seinen angranzenden Regionen in der Spätbronze-/Früheisenzeit, Beier \& Beran, Langenweißbach, pp. 65-78.

Photos, E. (1989). The question of meteoritic versus smelted nickel-rich iron: archaeological evidence and experimental results. World Archaeology 20: 403-421.

Pickles, S. (1988). Metallurgical Changes in Late Bronze Age Cyprus, Occasional Paper No. 17, Department of Archaeology, University of Edinburgh, Edinburgh.

Pigott, V. C. (1980). The Iron Age in western Iran. In Wertime, T. A., and Muhly, J. D. (eds.), The Coming of the Age of Iron, Yale University Press, New Haven, CT, pp. 417-461.

Pigott, V. C. (1981). The Adoption of Iron in Western Iran in the Early First Millennium BC: An Archaeometallurgical Study, Ph.D. dissertation, Department of Anthropology, University of Pennsylvania, Philadelphia.

Pigott, V. C. (1982). The innovation of iron: Cultural dynamics in technological change. Expedition 25(1): 20-25.

Pigott, V. C. (1989). The emergence of iron use at Hasanlu. Expedition 31(2-3): 67-79.

Pigott, V. C. (1999). The development of metal production on the Iranian plateau: An archaeometallurgical perspective. In Pigott, V. C. (ed.), The Archaeometallurgy of the Asian Old World, University of Pennsylvania Museum, Philadelphia, pp. 73-106.

Pigott, V. C. (2003). Iron and pyrotechnology at 13th century-Late Bronze Age Tel Yin'nam (Israel): A reinterpretation. In Stöllner, T., Körlin, G., Steffens, G., and Cierny, J. (eds.), Man and MiningMensch und Bergbau: Studies in Honour of Gerd Weisgerber on Occasion of his 65th birthday, Deutsches Bergbau-Museum, Bochum, pp. 365-375.

Pleiner, R. (1979). The technology of three Assyrian iron artifacts from Khorsabad. Journal of Near Eastern Studies 38: 83-91.

Pleiner, R., and Bjorkman, J. K. (1974). The Assyrian Iron Age: The history of iron in Assyrian civilization. Proceedings of the American Philosophical Society 118: 283-313.

Pollard, A. M. (2009). What a long, strange trip it's been: Lead isotopes and archaeology. In Shortland, A. J., Freestone, I. C., and Rehren, T. (eds.), From Mine to Microscope: Advances in the Study of Ancient Technology, Oxbow Books, Oxford, pp. 181-196.

Pseudo-Aristotle. (1936). On marvelous things heard. In Minor Works: On Colours. On Things Heard. Physiognomics. On Plants. On Marvellous Things Heard. Mechanical Problems. On Indivisible Lines. The Situations and Names of Winds. On Melissus, Xenophanes, Gorgias., trans. Hett, W. S., Harvard University Press, Cambridge, pp. 235-325.

Pulak, C. (1998). The Uluburun shipwreck: An overview. The International Journal of Nautical Archaeology 27: 188-224.

Pulak, C. (2008). The Uluburun shipwreck and Late Bronze Age trade. In Aruz, J., Benzel, K., and Evans, J. M. (eds.), Beyond Babylon: Art, Trade and Diplomacy in the Second Millennium BC, Metropolitan Museum of Art, New York.

Rademakers, F. W., Rehren, T., and Pernicka, E. (2017). Copper for the pharaoh: Identifying multiple metal sources for Ramesses' workshops from bronze and crucible remains. Journal of Archaeological Science 80: 50-73. 
Radivojević, M. (2015). Inventing metallurgy in western Eurasia: A look through the microscope lens. Cambridge Archaeological Journal 25: 321-338.

Rehder, J. E. (1991). The decorated iron swords from Luristan: Their material and manufacture. Iran 29: 13-19.

Rehren, T., Belgya, T., Jambon, A., Káli, G., Kasztovszky, Z., Kis, Z., Kovács, I., Maróti, B., MartinónTorres, M., Miniaci, G., Pigott, V. C., Radivojević, M., Rosta, L., Szentmiklósi, L., and SzőkefalviNagy, Z. (2013). 5,000 years old Egyptian iron beads made from hammered meteoritic iron. Journal of Archaeological Science 40: 4785-4792.

Rehren, T., Pusch, E. B., and Herold, A. (1998). Glass coloring works within a copper-centered industrial complex in Late Bronze Age Egypt. In McCray, P. (ed.), The Prehistory and History of Glassmaking Technology, American Ceramic Society, Westerville, OH, pp. 227-250.

Rice, R. E., and Rogers, E. M. (1980). Reinvention in the innovation process. Knowledge 1: 499-514.

Richardson, H. C. (1934). Iron, prehistoric and ancient. American Journal of Archaeology 38: 555-583.

Roames, J. (2011). The Early Iron Age metal workshop at Tell Tayinat, Turkey. In Vandiver, P., Li, W., Ruvalcaba Sil, J. L., Reedy, C. L., and Frame, L. D. (eds.), Materials Issues in Art and Archaeology IX, Cambridge University Press, Cambridge, pp. 149-155.

Roberts, B. W., and Radivojević, M. (2015). Invention as a process: Pyrotechnologies in early societies. Cambridge Archaeological Journal 25: 299-306.

Rogers, E. M. (2003). Diffusion of Innovations, Free Press, New York.

Rose, C. B., and Darbyshire, G. (eds.) (2011). The New Chronology of Iron Age Gordion, University of Pennsylvania Museum of Archaeology and Anthropology, Philadelphia.

Rothenberg, B. (1982). Rothenberg comment in discussion following Snodgrass. In Muhly, J. D., Maddin, R., and Karageorghis, V. (eds.), Acta of the International Archaeological Symposium on Early Metallurgy in Cyprus, 4,000-500 BC, Larnaca, Cyprus 1-6 June 1981, Pierides Foundation, Nicosia, p. 295.

Rothenberg, B. (ed.) (1990). The Ancient Metallurgy of Copper: Archaeology, Experiment, Theory, Institute for Archaeo-Metallurgical Studies, Institute of Archaeology, University College, London.

Rothenberg, B., and Tylecote, R. F. (1976). Some notes to "The occurrence of metallic iron in ancient copper." Journal of Field Archaeology 3: 236-237.

Rothenberg, B., and Tylecote, R. F. (1991). A unique Assyrian iron smithy in the northern Negev. Institute for Archaeometallurgical Studies Newsletter 17: 11-14.

Routledge, B., and McGeough, K. (2009). Just what collapsed? A network perspective on 'palatial and 'private' trade at Ugarit. In Bachhuber, C., and Roberts, R. G. (eds.), Forces of Transformation: The End of the Bronze Age in the Mediterranean, Oxbow Books, Oxford, pp. 22-29.

Sagona, A,. and Zimansky, P. (2009). Ancient Turkey, Routledge, London.

Schiffer, M. B. (2011). Studying Technological Change: A Behavioral Approach, University of Utah Press, Salt Lake City.

Seeher, J. (2010). After empire: Observations on the Early Iron Age in central Anatolia. In Singer, I. (ed.), Ipamati kistamati pari tumatimis: Luwian and Hittite Studies Presented to J. David Hawkin on the Occasion of His 70th Birthday, Emery and Claire Yass Publications in Archaeology, Institute of Archaeology, Tel Aviv Unviersity, Tel Aviv, pp. 220-229.

Sevin, V. (2003). The Early Iron Age in the Van region. In Smith, A. T., and Rubinson, K. S. (eds.), Archaeology in the Borderlands: Investigations in Caucasia and Beyond, Cotsen Institute of Archaeology, University of California, Los Angeles, pp. 185-196.

Shell, C. (1997). Analyses of iron, copper and related materials. In Oates, D., Oates, J., and Mcdonald, H. (eds.), Excavations at Tell Brak, Vol 1: The Mitanni and Old Babylonian Periods, McDonald Institute for Archaeological Research and the British School of Archaeoloy in Iraq, Cambridge, pp. $120-123$.

Sherratt, A., and Sherratt, S. (2001). Technological change in the east Mediterranean Bronze Age: Capital, resources and marketing. In Shortland, A. (ed.), The Social Context of Technological Change: Egypt and the Near East, 1650-1550 BC, Oxbow Books, Oxford, pp. 15-38.

Sherratt, S. (1993). Commerce, iron and ideology: Metallurgical innovation 12th-11th century Cyprus. In Karageorghis, V. (ed.), Cyprus in the 11th Century BC, A. G. Leventis Foundation, Athens, pp. 59-106.

Sherratt, S. (1998). 'Sea Peoples' and the economic structure of the late second millennium in the eastern Mediterranean. In Gitin, S., Mazar, A., and Stern, E. (eds.), Mediterranean Peoples in Transition: 13th through Early 10th Centuries BCE, Israel Exploration Society, Jerusalem, pp. 292-313. 
Sherratt, S. (2000). Circulation of metals and the end of the Bronze Age in the eastern Mediterranean. In Pare, C. F. E. (ed.), Metals Make the World Go Round: The Supply and Circulation of Metals in Bronze Age Europe, Oxbow Books, Oxford, pp. 82-98.

Siegelova, J. (1984). Gewinnung und Verartbeitung von Eisen im hethitischen Reich im 2. Jahrtausend v.u.Z. Annual of the Naprstek Museum 12: 71-178.

Skakov, A. Y. (2011). Pogrebal'nye yamy Kolkhidy (Grave pits of Colchis). In Albegova, Z. K., Bagaev, M. K., and Korenevskiy, S. N. (eds.), Voprosy Drevney i Srednevekovoy Arkheologii Kavkaza (Questions of Ancient and Medieval Archaeology of the Caucasus), Uchrezhdeniye Rossiyskoy Akademii Nauk Institut Arkheologii, Grozny, Russia, pp. 95-113.

Smith, A. T., Badalyan, R. S., and Avetisyan, P. S. (2009). The Archaeology and Geography of Ancient Transcaucasian Societies, Volume 1: The Foundations of Research and Regional Survey in the Tsaghkahovit Plain, Armenia, Oriental Institute, University of Chicago, Chicago.

Smith, C. S. (1965). Materials and the development of civilization and science. Science 148: 908-917.

Smith, C. S. (1967). The interpretation of microstructures of metallic artifacts. In Application of Science in the Examination of Works of Art: Proceedings of the Seminar: September 7-16, 1965, Museum of Fine Arts, Boston, pp. 20-52.

Smith, C. S. (1971). The techniques of the Luristan smith. In Brill, R. H. (ed.), Science and Archaeology, MIT Press, Cambridge, pp. 32-54.

Smith, J. S. (2009). Art and Society in Cyprus from the Bronze Age into the Iron Age, Cambridge University Press, Cambridge.

Snodgrass, A. M. (1971). The Dark Age of Greece: An Archaeological Survey of the Eleventh to the Eighth Centuries BC, Edinburgh University Press, Edinburgh.

Snodgrass, A. M. (1980). Iron and early metallurgy in the Mediterranean. In Wertime, T. A., and Muhly, J. D. (eds.), The Coming of the Age of Iron, Yale University Press, New Haven, CT, pp. $335-374$.

Snodgrass, A. M. (1982). Cyprus and the beginnings of iron technology in the eastern Mediterranean. In Muhly, J. D., Maddin, R., and Karageorghis, V. (eds.), Acta of the International Archaeological Symposium on Early Metallurgy in Cyprus, 4,000-500 BC, Larnaca, Cyprus 1-6 June 1981, Pierides Foundation, Nicosia, pp. 285-295.

Sørensen, M. L. S. (1989). Ignoring innovation-denying change: The role of iron and the impact of external influences on the transformation of Scandinavian societies 800-500 BC. In van der Leeuw, S. E., and Torrence, R. (eds.), What's New? A Closer Look at the Process of Innovation, Unwin Hyman, London, pp. 182-202.

Soulignac, R. (2017). Les Scories de Forge du Pays Dogon (Mali): Entre ethnoarchéologie, archéologie expérimentale et archéométrie, LIBRUM, Hochwald/Basel, Switzerland.

South, A. (2012). Tinker, tailor, farmer, miner: Metals in the Late Bronze Age economy at Kalavasos. In Kassianidou, V., and Papasavvas, G. (eds.), Eastern Mediterranean Metallurgy and Metalwork in the Second Millennium BC, Oxbow Books, Oxford, pp. 35-47.

Stech-Wheeler, T., Muhly, J. D., Maxwell-Hyslop, K. R., and Maddin, R. (1981). Iron at Taanach and early iron metallurgy in the eastern Mediterranean. American Journal of Archaeology $\mathbf{8 5}$ : 245-269.

Stech, T. (1982). Urban metallurgy in Late Bronze Age Cyprus. In Muhly, J. D., Maddin, R., and Karageorghis, V. (eds.), Acta of the International Archaeological Symposium on Early Metallurgy in Cyprus, 4,000-500 BC, Larnaca, Cyprus 1-6 June 1981, Pierides Foundation, Nicosia, pp. $105-115$.

Stöllner, T., Samaschev, Z., Berdenov, S., Cierney, J., Doll, M., Garner, J., Gontscharov, A., Gorelik, A., Hauptmann, A., Herd, R., Kusch, G. A., Merz, V. A., Piese, T., Sikorski, B., and Zickgraf, B. (2011). Tin from Kazakhstan-Steppe tin for the West? In Yalçin, Ü. (ed.), Anatolian Metal V, Deutsches Bergbau-Museum, Bochum, pp. 231-251.

Stos-Gale, Z. A., Maliotis, G., Gale, N. H., and Annetts, N. (1997). Lead isotope characteristics of the Cyprus copper ore deposits applied to provenance studies of copper oxhide ingots. Archaeometry 19: $83-123$.

Tavadze, T. N., Inanishvili, G. V., Sakvarelidze, T. N., and Zagyu, T. H. (1984). Issledovaniye drevnikh shlakov zhelezhogo proizvodstva na territorii Gruzii (Investigation of ancient slags of iron production on the territory of Georgia).In History of Science, Metsniereba, Tbilisi, pp. 20-25.

Thér, R., Mangel, T., and Gregor, M. (2017). Potter's wheel in the Iron Age in central Europe: Process or product innovation? Journal of Archaeological Method and Theory 24: 1256-1299. 
Tholander, E. (1971). Evidence for the use of carburized steel and quench hardening in Late Bronze Age Cyprus. Opuscula Atheniensia 10: 15-22.

Thornton, C. P. (2009a). Archaeometallurgy: Evidence of a paradigm shift? In Kienlin, T. L., and Roberts, B. W. (eds.), Metals and Societies: Studies in Honour of Barbara S. Ottaway, R. Habelt, Bonn, pp. 25-33.

Thornton, C. P. (2009b). The emergence of complex metallurgy on the Iranian Plateau: Escaping the Levantine paradigm. Journal of World Prehistory 22: 301-327.

Thornton, C. P., and Pigott, V. C. (2011). Blade-type weaponry of Hasanlu period IVb. In de Schauensee, M. (ed.), Peoples and Crafts in Period IVb at Hasanlu, Iran, University of Pennsylvania Press, Philadelphia, pp. 135-182.

Tylecote, R. F. (1981). Iron sands from the Black Sea. Anatolian Studies 31: 137-139.

Tylecote, R. F. (1982). Late Bronze Age: Copper and bronze metallurgy at Enkomi and Kition. In Muhly, J. D., Maddin, R., and Karageorghis, V. (eds.), Acta of the International Archaeological Symposium on Early Metallurgy in Cyprus, 4,000-500 BC, Larnaca, Cyprus 1-6 June 1981, Pierides Foundation, Nicosia, pp. 81-100.

Tylecote, R. F., Austin, J. M., and Wraith, A. E. (1971). The mechanism of the bloomery process in the shaft furnaces. Journal of the Iron and Steel Institute 209: 243-363.

Veenhof, K. R. (2016). A difficult Old Assyrian business venture: Mannum-kī-Aššur tries his luck with iron. Bibliotheca Orientalis 73: 13-39.

Veldhuijzen, H. A. (2009a). Hip to be square: How tuyères shapes the Hammeh technology. In Gebel, H. G., Kafafi, Z., and Ghul, O. (eds.), Modesty and Patience: Archaeological Studies and Memories in Honour of Nabil Qadi (Abu Salim), Ex Oriente, Berlin, pp. 114-125.

Veldhuijzen, H. A. (2009b). Of slags and scales; Micro-stratigraphy and micro-magnetic material at metallurgical excavations. In Kaptijn, E., and Petit, L. P. (eds.), A Timeless Vale: Archaeology and Related Studies of the Jordan Valley, Leiden University Press, Leiden, pp. 163-174.

Veldhuijzen, H. A. (2009c). Red hot: The smithy at Tel Beth-Shemesh. Near Eastern Archaeology 72: $129-131$.

Veldhuijzen, H. A. (2012). Just a few rusty bits: The innovation of iron in the eastern Mediterranean in the 2nd and 1st millennia BC. In Kassianidou, V., and Papasavvas, G. (eds.), Eastern Mediterranean Metallurgy and Metalwork in the Second Millennium BC, Oxbow Books, Oxford, pp. 237-250.

Veldhuijzen, H. A., and Rehren, T. (2007). Slags and the city: Early iron production at Tell Hammeh, Jordan and Tel Beth-Shemesh, Israel. In La Niece, S., Hook, D., and Craddock, P. (eds.), Metals and Mines: Studies in Archaeometallurgy, Archetype Publications, London, pp. 189-201.

Voigt, M. M., and Hendrickson, R. C. (2000). Formation of the Phrygian state: The Early Iron Age at Gordion. Anatolian Studies 50: 37-54.

Waldbaum, J. C. (1978). From Bronze to Iron: The Transition from the Bronze Age to the Iron Age in the Eastern Mediterranean, P. Aström, Göteborg.

Waldbaum, J. C. (1980). The first archaeological appearance of iron and the transition to the Iron Age. In Wertime, T. A., and Muhly, J. D. (eds.), The Coming of the Age of Iron, Yale University Press, New Haven, CT, pp. 69-98.

Waldbaum, J. C. (1982). Bimetallic objects from the eastern Mediterranean and the question of the dissemination of iron. In Muhly, J. D., Maddin, R., and Karageorghis, V. (eds.), Acta of the International Archaeological Symposium on Early Metallurgy in Cyprus, 4,000-500 BC, Larnaca, Cyprus 1-6 June 1981, Pierides Foundation, Nicosia, pp. 325-349.

Waldbaum, J. C. (1999). The coming of iron in the eastern Mediterranean: Thirty years of archaeological and technological work. In Pigott, V. C. (ed.), The Archaeometallurgy of the Asian Old World, University of Pennsylvania Museum, Philadelphia, pp. 27-57.

Wartke, R.-B. (1991). Production of iron artifacts. In Merhav, R. (ed.), Urartu: A Metalworking Center in the First Millennium BCE, The Israel Museum, Jerusalem, pp. 321-331.

Wertime, T. A. (1964). Man's first encounters with metallurgy. Science 146: 1257-1267.

Wertime, T. A. (1973). The beginnings of metallurgy: A new look. Science 182: 875-887.

Wertime, T. A. (1983). The furnace versus the goat: The pyrotechnologic industries and Mediterranean deforestation in Antiquity. Journal of Field Archaeology 10: 445-452.

Wertime, T. A., and Muhly, J. D. (eds.) (1980). The Coming of the Age of Iron, Yale University Press, New Haven, CT.

Williams, A. R., and Maxwell-Hyslop, K. R. (1973). Ancient steel from Egypt. Journal of Archaeological Science 3: 283-305. 
Yagel, O. A., Ben-Yosef, E., and Craddock, a. P. T. (2016). Late Bronze Age copper production in Timna: New evidence from Site 3. Levant 48: 33-51.

Yahalom-Mack, N., and Eliyahu-Behar, A. (2015). The transition from bronze to iron in Canaan: Chronology, technology and context. Radiocarbon 57: 285-305.

Yahalom-Mack, N., Eliyahu-Behar, A., Martin, M. A. S., Kleiman, A., Shahack-Gross, R., Homsher, R. S., Gadot, Y., and Finkelstein, I. (2017). Metalworking at Megiddo during the Late Bronze and Iron Ages. Journal of Near Eastern Studies 76: 53-74.

Yahalom-Mack, N., Gadot, Y., Eliyahu-Behar, A., Bechar, S., Shilstein, S., and Finkelstein, I. (2014a). Metalworking at Hazor: A long-term perspective. Oxford Journal of Archaeology 33: 19-45.

Yahalom-Mack, N., Galili, E., Segal, I., Eliyahu-Behar, A., Boaretto, E., Shilstein, S., and Finkelstein, I. (2014b). New insights into Levantine copper trade: Analysis of ingots from the Bronze and Iron Ages in Israel. Journal of Archaeological Science 45: 159-177.

Yalçin, Ü. (1999). Early iron metallurgy in Anatolia. Anatolian Studies 49: 177-187.

Yalçin, Ü., and Özyiğit, Ö. (2013). Die Schmiedewerkstatt aus Phokaia: Ein Kurzbericht. In Yalçin, Ü. (ed.), Anatolian Metal VI, Deutsches Bergbau-Museum, Bochum, pp. 239-246.

Yener, K. A. (2000). The Domestication of Metals, Brill, Leiden.

Yener, K. A., Kulakoğlu, F., Yazgan, E., Kontani, R., Hayakawa, Y. S., Lehner, J. W., Dardeniz, G., Öztürk, G., Johnson, M., Kaptan, E., and Hacar, A. (2015). The discovery of new tin mines and production sites near Kültepe, ancient Kanesh in Turkey: A third-millennium BC highland production model. Antiquity 89: 596-612.

Yener, K. A., Ozbal, H., Kaptan, E., Pehlivan, A. N., and Goodway, M. (1989). Kestel: An Early BronzeAge source of tin ore in the Taurus Mountains, Turkey. Science 244: 200-203.

Yukushima, K. (2001). Iron arrowheads from Stratum II at Kaman-Kalehöyük. Anatolian Archaeological Studies/Kaman-Kalehöyük 10: 111-118.

\section{Bibliography of Recent Literature}

Akanuma, H. (2000). Manufacture and use of iron in the cultural period of stratum II at Kaman-Kalehöyük: Archaeometallurgical analysis of iron objects from that site. Anatolian Archaeological Studies/Kaman-Kalehöyük 9: 217-228.

Akanuma, H. (2004). Archaeometallurgical analysis of iron and copper objects from Stratum III and Stratum II at Kaman-Kalehöyük: Correlation between composition and archaeological levels. Anatolian Archaeological Studies/Kaman-Kalehöyük 13: 163-174.

Akanuma, H. (2005). Significance of the composition of excavated iron fragments from Statum III at Kaman-Kalehöyük, Turkey. Anatolian Archaeological Studies/Kaman-Kalehöyük 14: 147-157.

Bebermeier, W., Brumlich, M., Cordani, V., de Vincenzo, S., Eilbracht, H., Klinger, J., et al. (2016). The coming of iron in a comparative perspective. eTopoi Journal for Ancient Studies Special Volume 6: $152-189$.

Ben-Yosef, E., Levy, T. E., and Najjar, M. (2009). New Iron Age copper-mine fields discovered in southern Jordan. Near Eastern Archaeology 72: 98-101.

Ben-Yosef, E., Tauxe, L., and Levy, T. E. (2010). Archaeomagnetic dating of copper smelting site F2 in the Timna Valley (Israel) and its implications for the modelling of ancient technological developments. Archaeometry 52: 1110-1121.

Buchwald, V. F. (2005). Iron and Steel in Ancient Times, Det Kongelige Danske Videnskabernes Selskab, Copenhagen.

Charlton, M. F. (2015). The last frontier in 'sourcing': The hopes, constraints and future for iron provenance research. Journal of Archaeological Science 56: 210-220.

Çilingiroğlu, A., and Sagona, A. (eds.) (2012). Anatolian Iron Ages 7: Proceedings of the Seventh Anatolian Iron Ages Colloquium held at Edirne, 19-24 April 2010, British Institute at Ankara, London.

Fischer, B., Genz, H., Jean, É., and Köruoğlu, K. (eds.) (2003). Identifying Changes: The Transition from Bronze to Iron Ages in Anatolia and Its Neighboring Regions: Proceedings of the International Workshop, Istanbul, November 8-9, 2002, Türk Eskiçağ Bilimleri Enstitüsü, Istanbul.

Gambashidze, I., Hauptmann, A., Slotta, R., and Yalçin, Ü. (eds.) (2001). Georgien: Schätze aus dem Land des goldenen Vlies, Deutsches Bergbau-Museum, Bochum.

Hošek, J., Cleere, H., and Mihok, L. (eds.) (2011). The Archaeometallurgy of Iron: Recent Developments in Archaeological and Scientifc Research, Institute of Archaeology of the ASCR, Praha. 
Humphris, J., and Rehren, T. (eds.) (2013). The World of Iron, Archetype, London.

Kassianidou, V., and Knapp, A. B. (2005). Archaeometallurgy in the Mediterranean: The social context of mining, technology, and trade. In Blake, E., and Knapp, A. B. (eds.), The Archaeology of Mediterranean Prehistory, Blackwell, Malden, MA, pp. 215-251.

Kassianidou, V., and Papasavvas, G. (eds.) (2012). Eastern Mediterranean Metallurgy and Metalwork in the Second Millennium BC, Oxbow Books, Oxford.

Kontani, R. (2005). Searching for the origin of the "bronze swords with the iron core" in northwestern Iran and the Caucasus region. Iranica Antiqua 40: 397-421.

Kozbe, G. (2008). The transition from Late Bronze Age to Early Iron Age in the Upper Tigris region, southeastern Anatolia: Identifying changes in pottery. In Rubinson, K. S., and Sagona, A. (eds.), Ceramics in Transitions: Chalcolithic through the Iron Age in the Highlands of the Southern Caucasus and Anatolia, Peeters, Leuven, pp. 291-322.

Levy, T. E. (2009). Pastoral nomads and Iron Age metal production in ancient Edom. In Szuchman, J. (ed.), Nomads, Tribes, and the State in the Ancient Near East, Oriental Instiute, University of Chicago, Chicago, pp. 147-177.

Levy, T. E., Higham, T., Bronk Ramsey, C., Smith, N. G., Ben-Yosef, E., Robinson, M., Munger, S., Knabb, K., Schulze, J. P., Najjar, M., and Tauxe, L. (2008). High-precision radiocarbon dating and historical biblical archaeology in southern Jordan. Proceedings of the National Academy of Sciences USA 105: 16460-16465.

Malekzadeh, M., Hasanpur, A., and Hashemi, Z. (2017). Fouilles (2005-2006) à Sangtarashan, Luristan, Iran. Iranica Antiqua 52: 61-158.

Masubuchi, M., and Nakai, I. (2005). Scientific characterization of metallurgical slag excavated from Kaman-Kalehöyük (1). Anatolian Archaeological Studies/Kaman-Kalehöyük 14: 183-194.

Meliksetian, K., Kraus, S., Pernicka, E., Avetissyan, P. S., Devejian, S., and Petrosyan, L. (2011). Metallurgy of prehistoric Armenia. In Yalçin, Ü. (ed.), Anatolian Metal V, Deutsches Bergbau-Museum, Bochum, pp. 201-210.

Muscarella, O. W. (1994). North-western Iran: Bronze Age and Iron Age. In Çilingiroğlu, A., and French, D. H. (eds.), Anatolian Iron Ages 3: Proceedings of the Third Anatolian Iron Ages Colloquium Held at Van, 6-12 August 1990, Oxbow books, Oxford, pp. 139-147.

Omori, T., and Nakamura, T. (2007). Radiocarbon dating of archaeological materials excavated at Kaman-Kalehöyük: Second report. Anatolian Archaeological Studies/Kaman-Kalehöyük 16: 111-123.

Overlaet, B. (2003). The Early Iron Age in the Pusht-i Kuh, Luristan, Peeters, Leuven.

Overlaet, B. (2005). The chronology of the Early Iron Age in the Pusht-i Kuh, Luristan. Iranica Antiqua 40: $1-33$.

Pleiner, R. (2000). Iron in Archaeology: The European Boomery Selters, Archeologický ústav AV ČR, Praha.

Pleiner, R. (2006). Iron in Archaeology: Early European Blacksmiths, Archeologický ústav AV ČR, Praha.

Sagona, A. (1999). The Bronze Age-Iron Age transition in northeast Anatolia: A view from Sos Höyük. Anatolian Studies 49: 153-157.

Shaar, R., Lauxe, L., Ben-Yosef, E., Kassianidou, V., Lorentzen, B., Feinberg, J. M., and Levy, T. E. (2015). Decadal-scale variations in geomagnetic field intensity from ancient Cypriot slag mounds. Geochemistry, Geophysics, Geosystems 16: 195-214.

Weisgerber, G. (2003). Spatial organization of mining and smelting at Feinan, Jordan: Mining archaeology beyond the history of technology. In Craddock, P., and Lang, J. (eds.), Mining and Metal Production Through the Ages, British Museum Press, London, pp. 76-89.

Yalçin, Ü., Özbal, H., and Paşamehmetoğlu, A. G. (eds.) (2008). Ancient Mining in Turkey and the Eastern Mediterranean, Atılım University, Ankara.

Yener, K. A. (2010). Bulgarmaden: Thoughts about iron, Bolkardağ and the Taurus mountains. Iraq 72: 183-191.

Publisher's Note Springer Nature remains neutral with regard to jurisdictional claims in published maps and institutional affiliations. 